\title{
Self-evaluation Report to International Review Panel
}

WWTF Office 


\section{Imprint}

Wiener Wissenschafts-, Forschungs- und Technologiefonds WWTF

Vienna Science and Technology Fund

Schlickgasse 3/12, 1090 Wien/Vienna, Austria

$\mathrm{T}:+43(0) 14023143$

@office@wwtf.at

http://www.wwtf.at

Authors: Michael Stampfer, Michael Strassnig

(c) WWTF 2014, Layout: WWTF 
I. Purpose and Context of the Selfevaluation Report

II. WWTF - Organisational Information

1. Mission, Strategies, Aims, Norms and Values

2. WWTF's Organisational Structure

3. Financial Structure of WWTF

4. WWTF's Funding Activities

5. WWTF's System of Quality Assurance

6. Supplementry Activities of WWTF

III. WWTF in Context

1. The Austrian and the Viennese Research and Innovation Landscape

2. WWTF in the Austrian and Regional Funding Landscape: Niche Player

3. Addendum

IV. The Evaluation of WWTF in 2008 and its Follow Up

1. Aim and Content of the 2008 Evaluation
2. Recommendations of the $\mathbf{2 0 0 8}$ Review Panel and Their Implementation

\section{Self-assessment of Impacts}

1. Impacts on "People" 37

2. Impacts on "Organisations" 39

3. Impacts on "Communities" 39

4. Impacts on "Environments" $\quad 40$

5. Impacts on "Topics" 41

6. Impacts on "Research" 41

7. Strengths and Weaknesses / 44 Opportunities and Threats

VI. References 45

VII.Appendices $\quad 47$

1. List of Members of WWTF boards / 47 Office

2. WWTF Funded Persons and National / 49 International Awards

3. WWTF Juries
31

9

9

0

1

\section{5}

31





\section{LIST OF FREQUENTLY USED ABBREVIATIONS}

\begin{tabular}{ll}
\hline AAS & $\begin{array}{l}\text { Austrian Academy of Sciences } \\
\text { Österreichische Akademie der Wissenschaften }\end{array}$ \\
\hline AIT & AlT Austrian Institute of Technology GmbH \\
\hline BOKU & University of Natural Resources and Life \\
& Sciences, Vienna \\
& Universität für Bodenkultur Wien \\
\hline CeMM & Research Center for Molecular Medicine of the \\
& Austrian Academy of Sciences \\
& Research Center for Molecular Medicine of the \\
& Austrian Academy of Sciences \\
& European Research Council \\
\hline ERC & Austrian Science Fund \\
FWnds zur Förderung wissenschaftlicher & Forschung \\
\hline FW & Technologiefonds \\
\hline Gregor Mendel Institute of Molecular Plant \\
Biology
\end{tabular}

\section{WWTF Programmes}

\begin{tabular}{ll}
\hline Cl & SciENCE for Creative Industries \\
\hline CS & Cognitive Sciences \\
\hline ICT & Information and Communication Technology \\
\hline LS & Life Sciences \\
\hline MA & Mathematics and ... \\
\hline SC & Science Chairs \\
\hline SSH & Social Sciences and Humanities in Vienna \\
\hline VRG & $\begin{array}{l}\text { Vienna Research Groups for Young } \\
\text { Investigators }\end{array}$ \\
\hline
\end{tabular}





\section{PURPOSE AND CONTEXT OF THE SELF-EVALUATION REPORT}

This document is part of the 2013 impact evaluation of WWTF by an international Review Panel. It has been prepared by WWTF office. It is directed to the Review Panel in order to inform the panel about WWTF on its own account and contains mainly facts about us and our funding, but also some estimations how we see our work. The 2013 impact evaluation is the first of its kind since WWTF was founded in 2003. WWTF has been subject to an organisation-wide evaluation in 2008 . The purpose of this past evaluation was to assess WWTF's setup and procedures in how far these help to achieve its aims and its mission (see WWTF 2008 for the conclusions of the Review Panel). The framework for this 2013 self-evaluation report is being stated in the Terms of References (2013) for the Review Panel. The main goal for the current exercise is to assess the impacts WWTF has made on particular aspects of the Viennese research and innovation context.
This document has to be read within the context of further materials of the 2013 impact evaluation, in particular the case study by Dr. Grit Laudel (Technical University Berlin, Institute of Sociology) on selected impacts of WWTF. As Dr. Laudel's study arrived before this report has been finished, a few references to the case study could already be built in this report. Further data of WWTF will be provided to the panel; specifically the interviews which the members of the Review Panel will conduct during the meeting on December 2-3, 2013.

This document seeks to provide concise information on WWTF as an organisation and its activities; the context of the Austrian and Viennese research landscape; as a part of this report, it includes a self-assessment of WWTF about its impacts and an analysis of its strength and weaknesses. 



\section{WWTF - \\ ORGANISATIONAL INFORMATION}

\section{Mission, strategies, aims, norms and values}

\begin{abstract}
Strengthening Vienna's research excellence is WWTF's mission since its beginnings. Our basic values are: Keeping the focus on a few things which are good and relevant for and in Vienna, strong alignment to international standards of quality and being persistent and patient in aiming at these goals.
\end{abstract}

Wir stärken Exzellenz am Forschungsstandort Wien (Freely translated: "We strengthen excellent research and we strengthen Vienna as a research location.")

The main mission of the Vienna Science and Technology Fund has not changed since work started more than ten years ago. When we started in 2002, the first funding activities where preceded by a thorough analysis; and the Board of Directors decided to embark a clear strategy. WWTF received the mission to strengthen Vienna as a location of excellent research through funding projects and persons.

WWTF funds larger project grants, tenure track positions and professorships (the latter two for incoming people), and we concentrate on identified strengths of the Vienna research landscape. We believe in further building on already strong fields. This should help Vienna to become an even stronger research location. We use competitive instruments and international review and jury procedures. Wherever possible we try to support - through our instruments - beneficial organisational efforts and changes in the Vienna research landscape. The 2008 evaluation has reassured us on this path.
Research policy in Austria is heavily directed towards industrial needs, be it direct subsidies or incentives for science-industry collaboration. Scientific research, however, lacks sufficient funding. This is one main reason why WWTF concentrates on supporting top class research in universities and research organisations, serving communities that have shown impressive qualitative growth over the last decades. Through this form of funding we help to lay foundations for top graduates and excellent academic cooperation partners for industry.

As this report further on and in detail describes which fields WWTF is supporting, the following points shall give an idea about some underlying aims, norms and values:

- Few people and groups get quite large amounts of money: We believe in concentrating our (scarce) funds in a few areas and on larger grants.

- The playing field for research is global, so the benchmarks and the review / selection procedures are global as well: Our peer review processes and juries are both purely international.

- Needs of industry and society are served well with strong and top-class research as a foundation: We believe that strong research cores attract talent as well as entrepreneurial interest.

- We aim at thinking outside of boxes and thus we have a strong commitment to research that seeks to transgress boundaries be they institutionally or disciplinary. Hence, we seek to promote interdisciplinary research through our calls and stimulate collaboration and networking between Viennese researchers and their institutions.

- WWTF shall be a safe ground for researchers when entering so far uncharted territories. This means that high risk ventures in research are welcomed and po- 
tential failures are condition of the possibility for high gain and breakthroughs.

- The design of calls, grants and administrative relations has to be lightweight and customer-friendly: We have to learn constantly and we have open ears for developments and needs of researchers and their home institutions. The rules of our organisation shall follow the researchers' needs.

- Open ears does not mean "no strategy", nor does it mean short-termism: We show perseverance and sustainability when we fund areas and fields. However, the core set of rules and values and its impetus towards quality and excellence is not negotiable.

- We strongly aim for a long-term perspective in all the activities we do. This means to put great emphasis on the development of careers of researchers, in particular of early stage scientists.

- We try to couple rigour in funding procedures with analytical tools to understand our field. We aim to be partners for researchers and their institutions but we do not refrain from challenging the one or another long-rehearsed custom to elicit increased quality of research.

- Finally we are aware of the small size of our funding and employ a niche strategy. However, through the way we approach things, we see ourselves as a strong driver for change in the Viennese research landscape.

\section{WWTF's organisational structure}

\author{
WWTF is an independent fund and has two \\ boards: The Board of Directors as final deci- \\ sion making body of WWTF and the Advisory \\ Board which provides advice to the Board of \\ Directors. WWTF office is responsible for the \\ day-to-day management:
}

WWTF is a private, non for profit fund.' Hence, WWTF is not an agency of the Municipal administration and thus independent in its actions. WWTF was founded in 2001 by two individuals and a banking foundation, the "Stiftung zur Verwaltung von Anteilsrechten". The latter has stipulated to donate 2/3 of its annual profits to WWTF (see below). The annual transfer from the foundation forms the main source of income of WWTF.

WWTF has two boards: (1) The Board of Directors ("Vorstand") composed of six members: two persons who founded WWTF (and their successors, respectively); two representatives of the banking foundation and two academic representatives (see appendix for the member list). The Board of Directors is the final decision making body of WWTF and its main tasks are to define the overall strategy, lay down funding guidelines, adopt thematic programmes, decide on approval of applications for funding and to settle organisational, administrative and financial issues.

(2) The Advisory Board ("Kuratorium") is composed of 25 members (see Annex for the member list) about which $2 / 3$ are academics working in Vienna, most of them nominated by the six local scientific universities. The other members are sent from the Viennese local

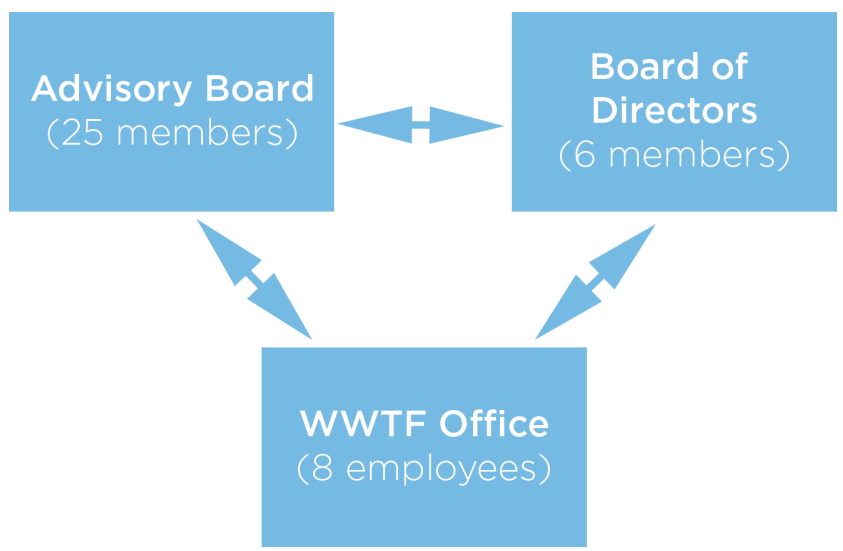


parliament, social partners and from municipal administration. Its main task is to provide advice to the Board of Directors in strategic and funding matters and other relevant issues.

(3) WWTF Office (see appendix for the employee list) is responsible for the Funds' on-going management and operation. It includes the preparation and management of calls, the processing of running projects, the execution of quality assurance and controlling instruments of all WWTF funding activities (ex-ante, interim and ex-post evaluation), the communication and interaction with funded persons and institutions as well as with other relevant stakeholders, and the administration of the fund itself. Currently, WWTF Office employs 8 people permanently (7.1 FTEs) for the management of its funding and other activities. WWTF office also provides consultancy via its 100\% subsidiary "WWTF GmbH". The latter has no own staff and has been founded due to tax reasons as WWTF is itself a non-profit organisation (See II.7. for projects of WWTF GmbH).

\section{Financial structure of WWTF}

WWTF has two financial sources for its funding activities: The banking foundation which provides about 7-8 m Euro per annum to WWTF. WWTF can decide in which thematic areas the money is invested. Further, WWTF is running programmes on behalf of the City of Vienna (VRG, SSH). This is about 4-5 m Euro per annum. Including all programmes, WWTF has invested more than 100 m Euro in Viennese research over the last 10 years.
WWTF has two sources for its funding activities. (1) It receives funds from the foundation "Privatstiftung zur Verwaltung von Anteilsrechten" once a year. This banking foundation is the result of banking merger including the successor of the Vienna Savings Bank. The bank finally merged with the "UniCredit Group". The foundation itself had been created to hold equity and to donate two thirds of its annual after-tax profits to WWTF for funding. (2) WWTF is managing programmes on behalf of the City of Vienna. These are the Vienna Research Groups for Young Investigators, Social Sciences and Humanities in Vienna, and also the University Infrastructure Programme (including different forms of management fees).

WWTF only dedicates money to calls for proposals and provides funding which it already has received. Liquidity reserves are managed within conservative portfolios by two banks: From 2002 until 2012 WWTF has been able to cover all costs from financial and other income, so that every Euro received from the foundation could be granted for projects.

On average (2003 to 2012), the overhead-percentage on the means attributed to funding was $7.7 \%$. These include personnel costs of WWTF office (3.76\%), as well as operating expenditures $(2.95 \%)$ and costs of call juries (0.99\%).

In total, from 2003-2013 WWTF provided 101.1 m Euro for the funding of research and researchers (including the currently open calls LS 2013 and VRG 2013). For those programme priorities subject to this evaluation, it is $83.6 \mathrm{~m}$ Euro (that is excluding the programmes "Science for Creative industries" and "Cognitive Sciences" and the still open calls for 2013). Additionally, the university infrastructure programme which is managed by WWTF on behalf of the City of Vienna provided $11 \mathrm{~m}$ Euro to the nine Viennese universities for infrastructure measures

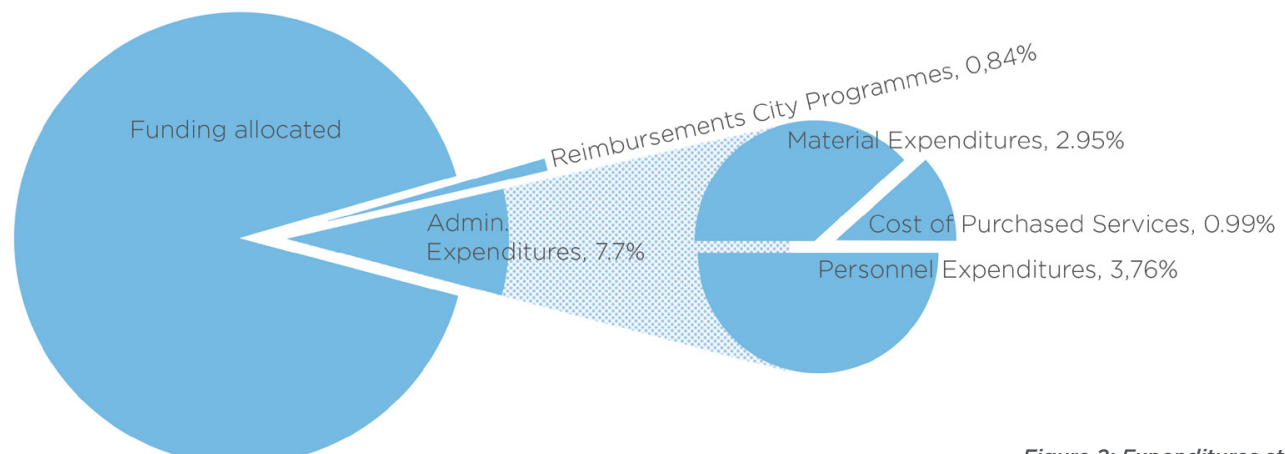

Figure 2: Expenditures structure including administrative costs of WWTF 
(not included in the fig. 3 below). While there is an overall growth of funding means which WWTF could provide, in the last years this growth is due to the means provided by the City of Vienna as an additional source for funding. The means WWTF received from the banking foundation remained more or less stable around 8 $m$ Euro per annum. Inflation and the increase of personnel costs every year, however, lead to a shrinking budget in real terms. A systematic shrinking of projects sizes, however, cannot be observed.

Besides WWTF own programmes funded by the financial means of the banking foundation, WWTF is currently managing three larger programmes for the City of $\mathrm{Vi-}$ enna:

- Social Sciences and Humanities in Vienna (since 2008, 5 calls): Thematic priorities are negotiated with the city of Vienna and must include relevance for the city. Management processes and thus quality assurance is, however, done according to WWTF's standards which includes solely international peer review and an international expert panel.

- The VRG programme is also funded by the City of Vienna (since 2010, 4 calls). Calls are (hitherto) launched within WWTF's thematic priorities, quality assurance of the selection of candidates is according to WWTF standards.

- University Infrastructure Programme (since 2006 annual calls) refunds property taxes to the 9 public universities in Vienna, thus is a non-competitive call as only the rector's offices can submit proposals. WWTF is administrating the submission, approving and accounting process.

\section{WWTF's funding activities}

WWTF's funding activities are organized along funding instruments (person-centred and project funding) and thematic programmes (currently: Life Sciences, Applied Mathematics, Cognitive Sciences, Information and Communication Technology, and Social Sciences and Humanities). The focus of funding is to strengthen existing research capabilities in the Viennese context, on interdisciplinarity and on the career possibilities of younger researchers.

In total, (2003 - incl. 2013) 30 calls have been organized. 21 have been project calls, 5 Science Chair calls and 4 are Vienna Research Groups calls. About $40 \%$ of the funding has been allocated to the Life Sciences, and about $20 \%$ each to Mathematics and to ICT.

The three institutions in Vienna which have received the greatest share of WWTF funding are: (1) the University of Vienna (25.5 m Euro), (2) Vienna University of Technology (16.8 m Euro), and (3) the Medical University of Vienna (15.6 m Euro).

WWTF's central activity is the funding of research and researchers in Vienna. Potential applicants always are Viennese institutions (no single persons) whose main
5.7
5.0

6.4

8.8

9.4

11.4

11.6

12.9
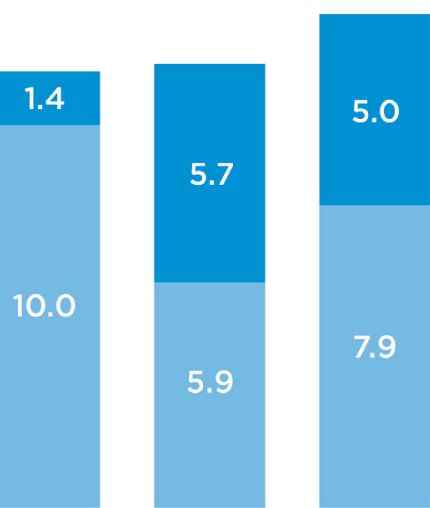

11.0

8.7
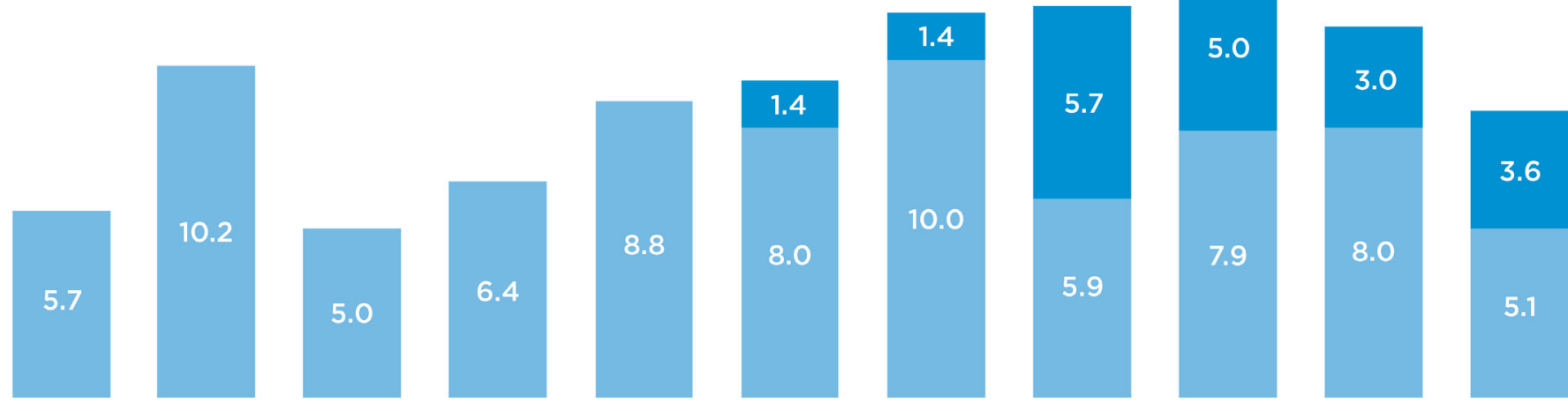

Figure 3: Funding budget by source and year (in $m €$ ).

All programme priorities excluding university infrastructure programme $\left({ }^{*}\right.$ indicates projected budgets).

- City of Vienna Banking Foundation 
purpose is the conduct of research. These include public and private universities, extra-university public research institutions and non-for-profit private research institutions. For-profit companies can be involved as project partners but will not receive funding from WWTF. Based on WWTF's central mission of strengthening Vienna's research capacities, non-Viennese institutions are not eligible to funding expect for a defined share of the budget as partners of Viennese institutions. This share is typically limited to $20 \%$ of the overall budget of the project.

WWTF's focus in funding research in Vienna is to build on existing capacities and provide sufficient resources to boost these areas. This should contribute to making them internationally more competitive and visible. WWTF also seeks to strengthen links both horizontally between different disciplines and research areas (interdisciplinarity) and vertically between basic and more applied oriented research. Special emphasis is also put on the career possibilities of young researchers ("Vienna Research Groups").

\section{Funding instruments}

WWTF employs three instruments to fund research:

(1) Major research projects usually involve a team of researchers led by a more experienced principal investigator to investigate a specific research question for two to four years. They are guided by a research plan which is evaluated ex ante. The funding budget is between 200.000 and $1 \mathrm{~m}$ Euro. In some calls, WWTF introduced an upper limit. On average, WWTF funding per project is about 500.000 Euro, which is substantially higher than the average project funding for research from comparable national sources. WWTF aims to equip projects with substantial resources for conducting their research. Funding covers personnel costs and all non-personnel costs that are directly attributed to the projects inclu- ding travel, management, consumables etc. Larger infrastructure items cannot be funded within project calls but depreciation rates are eligible. WWTF pays an overhead rate of $20 \%$ to the institution. Project participants must be employed by a Viennese research institution for the duration of the project. The main funding criteria for research projects are the scientific excellence of the applicants and the innovativeness and quality of the planned research.

(2) Person-oriented funding comes in two forms: (a) Science Chairs seek to attract more senior researchers from abroad to establish a research group in their field at their hosting institution in Vienna with a strong commitment of the future home institution (WWTF offers up to $1.5 \mathrm{~m}$ Euro for a maximum of five years. ${ }^{2}$ (b) Vienna Research Groups for Young Investigators (VRG) have been established in 2010 as a result of the innovation strategy of the City of Vienna. The programme is also financed by the City of Vienna. This instrument addresses younger academics coming from abroad to build their first own research group at the Viennese host institution. Funding volume is also $1.5 \mathrm{~m}$ Euro for $6-8$ years. It is required that the host institution offers to the group leader a longterm career perspective if he/she is positively evaluated. Host institutions must also provide a substantial financial / in kind contribution. Both Science Chair and VRG applicants need not to apply with a detailed research plan. The main selection criteria in person-oriented funding are the scientific excellence of the candidate and the potential and strategy to embed the new team into the existing research environment at the host institution (see also Chapter $\mathrm{V}$ ).

(3) A new, smaller instrument is the funding of summer schools with up to 25.000 Euro. It was first employed within the 2013 SSH call as a supplementary instrument to research projects. Summer schools must both involve international lecturers and students. In this context of 
the programme WWTF once offered fellowships which were not repeated because they were not successful).

\section{Thematic programmes}

A central characteristics of WWTF is that all funding activities are done within thematic priorities. Currently, WWTF issues calls in five different areas (for a detailed description see below):

\begin{tabular}{ll}
\hline Life Sciences & 2003 - today \\
\hline Mathematics and ... & 2004 - today \\
\hline Social Sciences and Humanities & 2008 - today \\
\hline Information and Communication & 2008 - today \\
Technology & $2008(2012)^{*}$ - today \\
\hline Cognitive Sciences & $2004-2006^{* *}$ \\
\hline Science for Creative Industries &
\end{tabular}

\section{Table 1: WWTF programmes and periods}

* Cognitive Sciences have been made an official programme priority in 2012. Before that, two Cognitive Sciences calls ran under the label "Science for Creative Industries" programme

** Formally ended 2012

This demonstrates that WWTF in general has a long term commitment on the funded areas, which is reflected by the ways to identify thematic areas. In 2002, WWTF conducted a strategy development process (see WWTF 2002) which resulted in the commitment to thematic and structure-oriented (such as interdisciplinarity as a requirement, for example) programmes rather than bottom-up funding without thematic limitations for applicants. Reasons for this commitment were the academic and public visibility of thematic programmes and its potential impact on the orientation of researchers; WWTF's position in the overall funding landscape as a regional actor with limited financial means without the responsibility to act as basic supplier for research money to all sciences; and organisation-internal reasons such

\section{Cognitive Sciences}

Social Sciences and Humanities

Information and Communication Technology

SCIENCE for Creative Industries

Mathematics and ... Life Sciences

Table 3: Overview of all WWTF calls

Caption: PRO ... Project; SC ... Science Chair; VRG ... Vienna Research Group; SUS ... Summer Schools
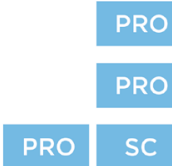

as the development of competences and organisational learning, and the costs of administration; finally the financial limitations of WWTF.

\begin{tabular}{ll}
$\begin{array}{l}\text { Number of Calls (including LS13 and VRG13 } \\
\text { which are still running) }\end{array}$ & 32 \\
\hline $\begin{array}{l}\text { Number of proposals submitted to WWTF* } \\
\text { Number of funded applications }\end{array}$ & 1128 \\
\hline $\begin{array}{l}\text { Information and Communication Technology } \\
\text { Table 2: Call statistics overview 2003-2013 }\end{array}$ & $17.6 \%$ \\
\hline "Excluding the currently running calls LS 2013 and VRG 2013.
\end{tabular}

The making of thematic priorities is subject to a process that is characterized by an open, non-formalized process. The first step is finding ideas (input from local and international experts, studies etc.), followed by an evaluation scheme by which the ideas are assessed, analysed by WWTF office, leading to discussions and recommendations by the WWTF Advisory Board, and finally leading to a formal decision of the WWTF Board of Directors. The criteria for the ex-ante validation of thematic priorities are consistent with WWTF's mission and goals: (1) the fit (complement) with existing measures (does WWTF have an USP?), (2) the support of the Viennese innovation policy, (3) a critical mass of potential applicants, (4) a given degree of excellence in basic research in that area in Vienna, (5) the potential to develop a critical size in Vienna, (6) potential of increased networking between Viennese research institutions, (7) international relevance of the thematic scope, (8) mid-term societal and economic benefits and utilisation (as a consequence of scientific excellence). To assess these criteria, WWTF uses external studies, interviews with relevant stakeholders/experts, literature review etc.

In total, WWTF was engaged in six distinctive areas of funding. It started with three areas and after five years

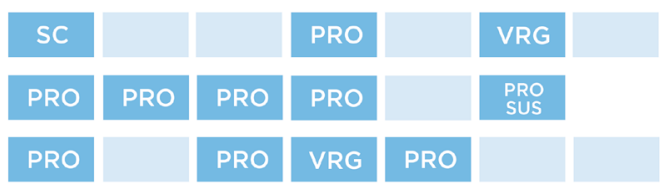

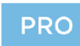

PRO

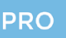

SC

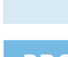

SC

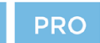

PRO

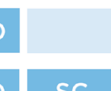

PRO
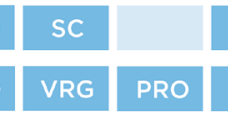

SC PRO

VRG

VRG

200320042005 
3 FWF uses a different categori-

zation of the disciplines. In total,

Biology, Human Medicine \& Health

Sciences, and Agricultural Scien-

ces \& Veterinary Medicine receive

a $40.6 \%$ share of FWF funding

(average of 2008-2012)

4 The share of Mathematics in FWF

funding (average of 2008-2012)

is $8.1 \%$ for Vienna; and $4 \%$ for ICT-

research in Vienna.

of activity, three additional areas have been added. From these six areas, one thematic priority was abandoned.

About $40 \%$ of the funding money went into the funding of Life Sciences. About $20 \%$ each were dedicated to Mathematics and ICT. The share for the social sciences is below $10 \%$ (however, the programme is only running since 2008), also the overall share for the Cognitive Sciences is low, but this programme has been running since 2008 too.

A comparison to the allocation of funding money with that of the Austrian Science Fund (FWF) is difficult, due to scale (20 times more funding money than WWTF), scope and strategic orientation. WWTF seeks its strengths in specific areas and niches. WWTF's and FWF's relative share for the life sciences in Vienna in their budgets is nearly the same (of about $40 \%$ ). ${ }^{3}$ Life Sciences are a both national and in particular local a priority of science policy and WWTF provides substantial input to this area. The uniqueness of WWTF funding in this area comes from an internal specialisation (e.g. translation between "basic" research and the clinic). In Mathematics and ICT, the engagement of WWTF is considerable. ${ }^{4}$ In the last five years, WWTF provided $8.3 \mathrm{~m}$ Euro to Mathematics in Vienna (2008-2012), FWF provided $36.7 \mathrm{~m}$ Euro. In ICT, WWTF provided $18.1 \mathrm{~m}$ Euro, FWF 18 m Euro (2008-2012).

\section{Life Sciences}

Life Sciences were the first thematic priority for which WWTF issued a call. This area is one of the main and traditional strengths in the research landscape in Vienna dating back to the foundation of institutes beyond traditional academic structures in the 1980 s (see Wirth 2013) and received great financial commitment of the federal government as well as from the City of Vienna. These efforts resulted in internationally recognized life scien- ces research institutions and in a vibrant and dynamic research landscape in the life sciences in Vienna.

WWTF contribution and value added to this already strong area is (1) the funding of larger, financially wellequipped projects, (2) the bridging between initiatives, disciplines and institutions, (3) bringing excellent people to Vienna from abroad and (in the case of Science Chairs) where expertise was not covered by Viennese institutions so far. All life sciences calls did also address sub-themes of the field in order to be complementary to existing funding and research, to create novel playing fields (e.g. links to clinical research) in the light of the large size of this field in Vienna (see, for example, Technopolis / Fraunhofer ISI 2006; LISAvienna 2013).

\begin{tabular}{|c|c|}
\hline Project Calls & 7 \\
\hline Funded Projects & 51 \\
\hline Person-funding Calls & 3 \\
\hline Funded Persons & 6 \\
\hline Total Sum Project Funding & $€ 28.411 .136$ \\
\hline Average Project Size & $€ 557.669$ \\
\hline Total Sum Person Funding & $€ 8.997 .500$ \\
\hline Average Project Size & $€ 1.499 .583$ \\
\hline Total Sum Funding & $€ 37.438 .636$ \\
\hline Acceptance Rate & $13.6 \%$ \\
\hline PI Male/Female Ratio & $79: 21$ \\
\hline
\end{tabular}

Table 4: WWTF funding in the Life Sciences, 2003 - 2012

\section{Mathematics and ...}

The Mathematics and ... programme dates back into 2004 and was the second big priority of WWTF after Life Sciences. Mathematics has a great tradition in $\mathrm{Vi}$ enna and could uphold its excellence until now. Many

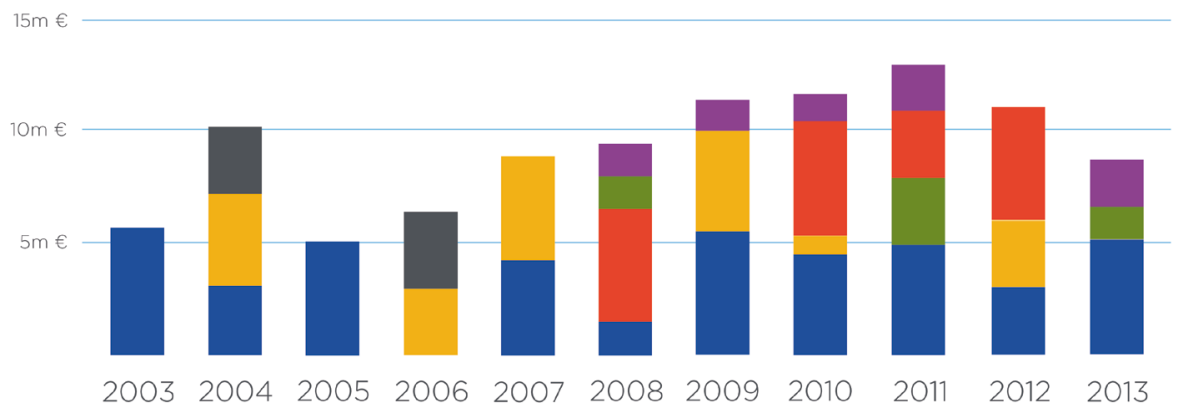

Social Sciences and Humanities Cognitive Sciences Information and Communication Technology SciENCE for Creative Industries Mathematics and... Life Sciences 
groups deliver internationally competitive results (See FWF 2007). The idea of the programme was to give that field a certain momentum by bridging it to applications and to other disciplines in order to initiate potential midterm benefits in terms of applications. The programme requires applicants to involve a partner from another discipline and hereby focuses on interdisciplinary modelling.

\begin{tabular}{|c|c|}
\hline Project Calls & 3 \\
\hline Funded Projects & 29 \\
\hline Person-funding Calls & 3 \\
\hline Funded Persons & 6 \\
\hline Total Sum Project Funding & $€ 13.163 .000$ \\
\hline Average Project Size & $€ 453.897$ \\
\hline Total Sum Person Funding & $€ 6.794 .050$ \\
\hline Average Project Size & $€ 1.132 .342$ \\
\hline Total Sum Funding & $€ 19.957 .050$ \\
\hline Acceptance Rate & $23.9 \%$ \\
\hline PI Male/Female Ratio & $86: 14$ \\
\hline
\end{tabular}

Table 5: WWTF funding in Mathematics, 2004 - 2012

\section{Information and Communication Technology}

The programme priority of Information and Communication Technology was introduced in 2008 and seeks to reinforce the strong position of ICTs in the Vienna through more fundamental research projects. While the applied side of ICTs is both covered by abundant national and supranational funding, there is a clear lack in funding more basic-oriented research projects in the ICTs. The programme's focus is on the understanding of substan- tial scientific research questions not with immediate but with mid-term social and economic benefits.

\begin{tabular}{|c|c|}
\hline Project Calls & 3 \\
\hline Funded Projects & 32 \\
\hline Person-funding Calls & 1 \\
\hline Funded Persons & 2 \\
\hline Total Sum Project Funding & $€ 15.090 .800$ \\
\hline Average Project Size & $€ 471.588$ \\
\hline Total Sum Person Funding & $€ 3.000 .000$ \\
\hline Average Project Size & $€ 1.500 .000$ \\
\hline Total Sum Funding & $€ 18.090 .800$ \\
\hline Acceptance Rate & $17.8 \%$ \\
\hline PI Male/Female Ratio & $85: 15$ \\
\hline
\end{tabular}

Table 6: WWTF funding in Information and Communication Technology, 2008 $-2012$

\section{Social Sciences and Humanities in Vienna}

The programme Social Sciences and Humanities in Vienna is not funded by own WWTF capital provided by the banking foundation but by financial means of the City of Vienna. It is a "starting project" within the 2007 RTDI strategy of the City of Vienna "Wien denkt Zukunft" (see Stadt Wien 2007). Historically, Vienna had a strong tradition in the social sciences and humanities, however, successively lost momentum due to a variety of reasons (external and internal) resulting in the fact that a certain proportion of Vienna's SSH research is not fully on par with international development but owns substantial innovativeness which can be developed and linked to international research. On the one hand, the programme aims to internationalize the SSHs in terms of their scientific quality. On the other hand, the programme is struc-

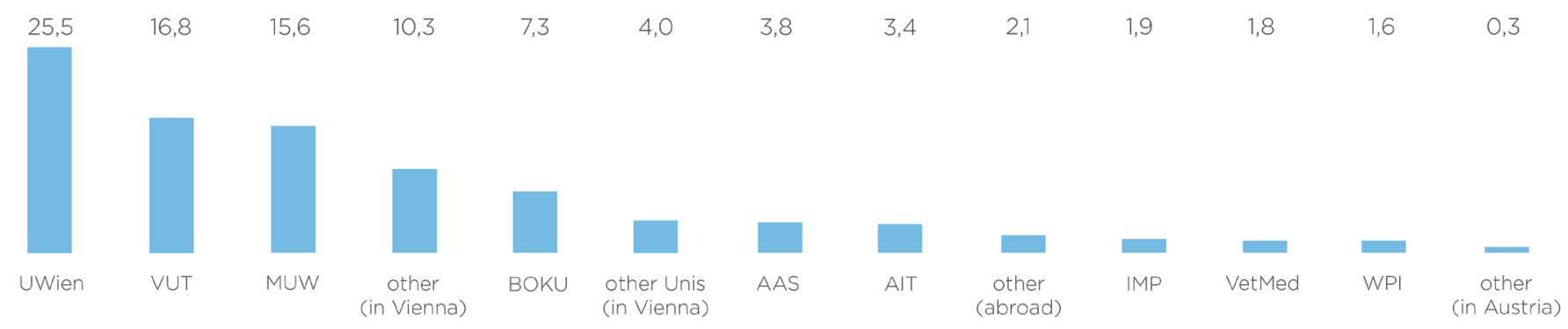

Figure 5: WWTF funding of institutions, total 2003-2013 (in million Euro).

The table includes total WWTF funding (incl. "Science for creative industries", "Cognitive Sciences"). The "University Infrastructure Programme" is not included. The currently open life sciences call 2013 is also not included. Max F. Perutz Laboratories are attributed to the University of Vienna with 60\% and to the Medical University of Vienna with 40\%. "Other U" mean smaller universities in Vienna (in terms of research), i.e. the three art universities, the Vienna University of Business and Economics. "Other (Vienna)" summarizes a large number of small private organisations that are in particular active in the areas of SSH and Cl. 
5 For 2012 alone, the Medical University of Vienna received $84.5 \mathrm{~m}$ Euro for research from third-party sources, however, a substantial part comes from enterprises for clinical research. The University of Vienna received $76.7 \mathrm{~m}$ Euro, the Vienna University of Technology received 71,7 $\mathrm{m}$ Euro, the Vienna University of Technology and the Natural Resources and Life Sciences received $35.8 \mathrm{~m}$ Euro, Source: uni:data / Wissensbilanz 2012.

tured by thematic calls which all take on issues that are relevant for urban contexts in general and for the city of Vienna in particular. So far, three thematic foci have been subject to calls: interdisciplinary work at the interface of art and science, diversity and identity, and public spaces.

\begin{tabular}{|c|c|}
\hline Project Calls & 5 \\
\hline Funded Projects & 26 \\
\hline Funded Persons & 3 \\
\hline Funded Summer Schools & 5 \\
\hline Total Sum Project Funding & $€ 7.764 .200$ \\
\hline Average Project Size & $€ 298.623$ \\
\hline Total Sum Person Funding & $€ 214.800$ \\
\hline Average Project Size & $€ 71.600$ \\
\hline Total Sum Summer School Funding & $€ 119.008$ \\
\hline Average Project Size & $€ 23.802$ \\
\hline Total Sum Funding & $€ 8.098 .008$ \\
\hline Acceptance Rate & $9.9 \%$ \\
\hline PI Male/Female Ratio & $47: 53$ \\
\hline
\end{tabular}

Table 7: WWTF funding in the Social Sciences and Humanities, 2008 - 2013

Two programmes of WWTF, "Science for Creative Industries" (Cl) and its successor "Cognitive Sciences" (CS) are not included here as CI was given up 2006 and CS has only started recently so that an assessment of impacts would not be reasonable.

\section{Institutional distribution of funding money}

Figures 5 and 6 describe how much money different institutions received from WWTF. In total, the University of Vienna received the greatest share of WWTF funding, followed by the Vienna University of Technology, the Medical University of Vienna and the University of Natural Resources and Life Sciences Vienna. Compared to the revenues from third-party-funding universities received beyond WWTF funding, the shares are not radically different from the picture WWTF funding provides. Including all third-party funding sources, the Medical University of Vienna is first, however, this calculation includes funding for relatively expensive clinical trial from enterprises, followed by the University of Vienna, the Vienna University of Technology and the University of Natural Resources and Life Sciences Vienna. ${ }^{5}$

Note that WWTF contributes only to a few per cent of the annual third-party funding of these institutions (Max. F. Perutz Laboratories are co-owned by UWien and MUW (60:40). Therefore, fig. 5 shows the distribution with MFPL as part of the both universities, fig. 6 . displays MFPL as a distinctive entity).

\section{Gender distribution of researchers in WWTF calls}

WWTF engaged with the Gender issue several years ago and extensively discussed it with both boards. For this evaluation, we refer to an extensive analysis for the Board in March 2012. We analysed 22 calls from 2003 and 2011, including 13 project calls of activities funded by WWTF means and four project calls funded by financial means of the city of Vienna in the SSH (since 2008), further three Science Chair calls and 2 calls for Vienna Research Group leaders.

The following figure 7 details the gender ratio in WWTF calls of those who submitted applications. About $30 \%$ of proposers are women.
21,6
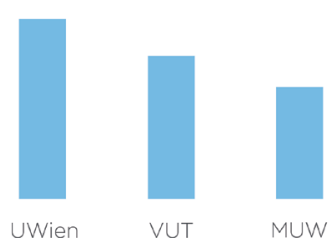
UWien
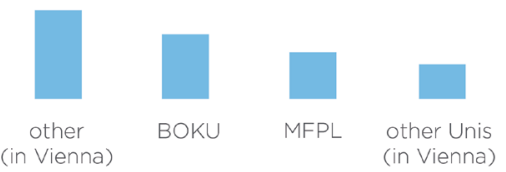
(in Vienna)
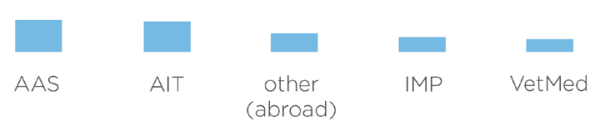
other (in Austria)

Figure 6: WWTF funding of institutions, total 2003-2013 (in million Euro), MFPL explicitly stated

The table includes total WWTF funding (incl. "Science for creative industries", "Cognitive Sciences"). The "University Infrastructure Programme" is not included. The currently open life sciences call 2013 is also not included. "Other Unis" mean smaller universities in Vienna (in terms of research), i.e. the three art universities, the Vienna University of Business and Economics. "Other (Vienna)" summarizes a large number of small, private organisations which are in particular active in the areas of SSH and Cl. 


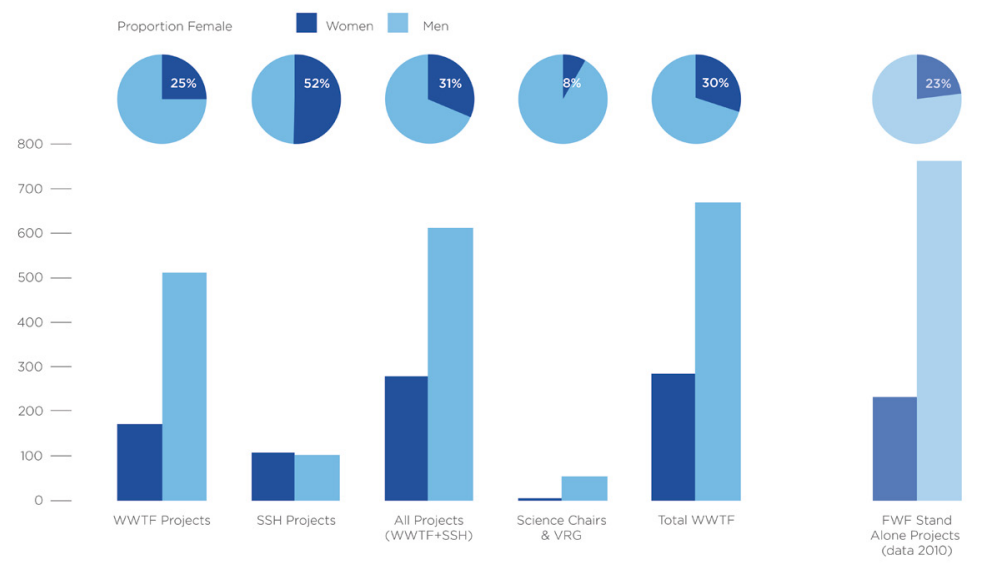

Figure 7: Gender ratio of PIs of WWTF applications, 2003-2011

This is a sound figure given that WWTF also to a great extent has to rely on its environment of research institutions and the population there. The gender balance of the three institutions which have received the greatest share of funding means are the University of Vienna that has $26.4 \%$ of female positions." The figure of the University of Vienna reflects a university which offers the full spectrum of studies and disciplines. Vienna University of Technology offers dominantly natural sciences and engineering disciplines. Here, the share of female staff is 9.7 $\%$. The Medical University of Vienna is a dominantly active in the Life Sciences and has a greater share of female scientists, $36.8 \%$

6 All data from the "Wissensbilanz" of the universities in 2012. The figure includes full professors, permanent and fixed termed contract, university lecturers (Universitätsdozent/in) associated and assistant professors.
The following figure 8 shows the gender ratio of the PIs in WWTF funded activities.

In total, the figure 10 confirms that the share of women submitting proposals and those finally funded is not decreasing significantly.

Based on the on-going discussion in and between the Board of Directors, Advisory Board and WWTF office, WWTF has elaborated a gender equality plan. It is strongly geared to that of the European Research Council.?
7 See http://erceuropa.eu/sites/de- fault/files/document/file/erc_scc gender_equality_plan_2007_2013. pdf
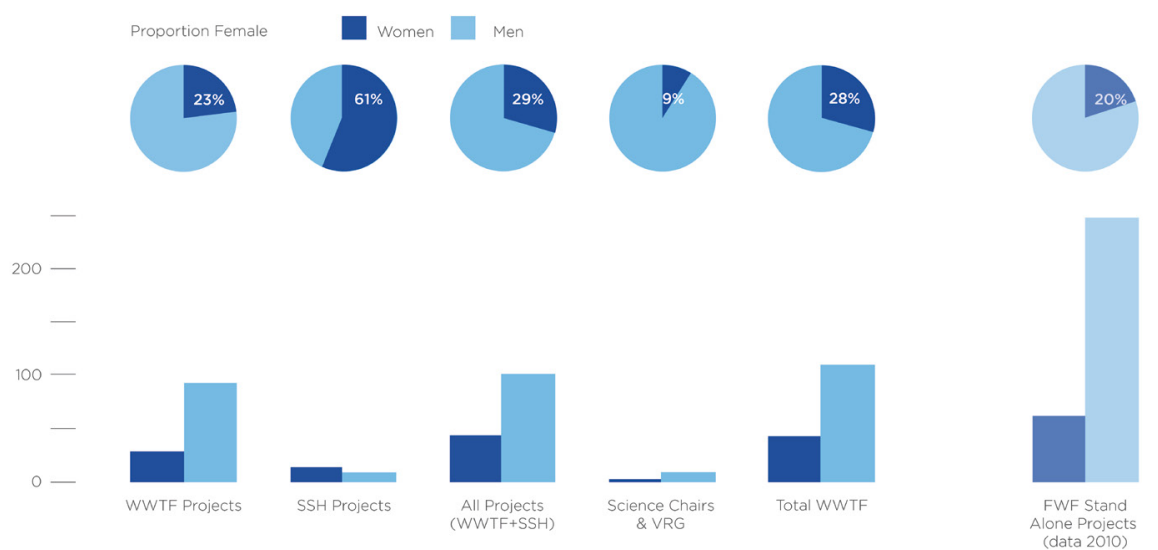


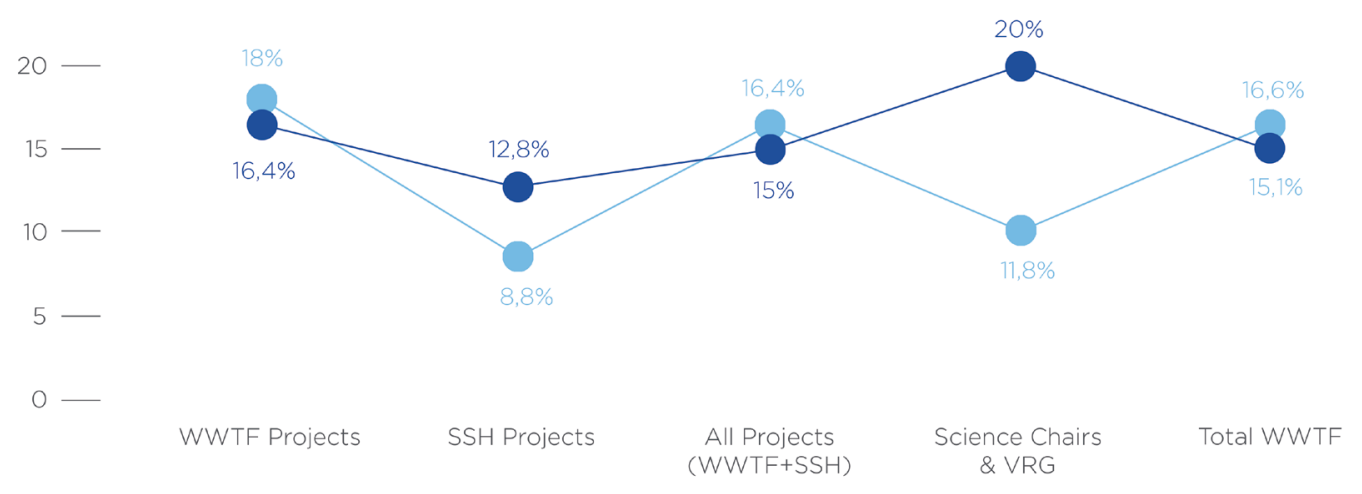

Figure 9: Approval ratio of male and female PIs in WWTF calls, 2003-2011

Each package includes a series of measures targeting to increase the share of women funded by WWTF and also maintaining scientific quality as the main criterion of funding. E.g. in "Submission", WWTF has organized proposers' days for women involving already WWTFfunded female PIs as role models. In "Evaluation" a 50:50 ratio of female and male jury members is aimed for and was reached for 2012 and 2013 (see annex). Jury panel members are asked to take unusual career paths into consideration. Gender balance in all WWTF activities is constantly monitored. All measures are constantly internally reviewed and further developed.

\section{WWTF's system of quality assurance}

\author{
WWTF has a comprehensive quality assurance \\ system, both chronological (from ex ante to ex \\ post) and in a structural order (from funded \\ cases to the institution). International peer re- \\ view and international jury processes within \\ competitive calls are at the core of the quality \\ assurance measures.
}

Quality assurance is an essential part for the funding activities of WWTF since its beginning. The evaluation concept dates back to 2004 and has been adopted and developed further (last modified in 2011). International peer review and international jury processes are at the core of the quality assurance measures. Both quickly became pivotal for WWTF since its founding and have successively been embedded in a comprehensive evaluation system. The 2008 Review Panel, after having a close look at WWTF procedures, came to the following conclusion: "The WWTF has set up a purely international peer review process that is living up to highest international standards. It is a professionally safe and sound process" ( $p .18$ ). The quality assurance matrix involves both the dimension of time (ex ante / interim / ex post) and different organisational levels of WWTF:
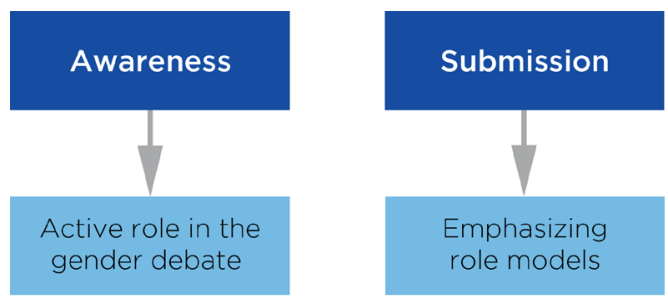
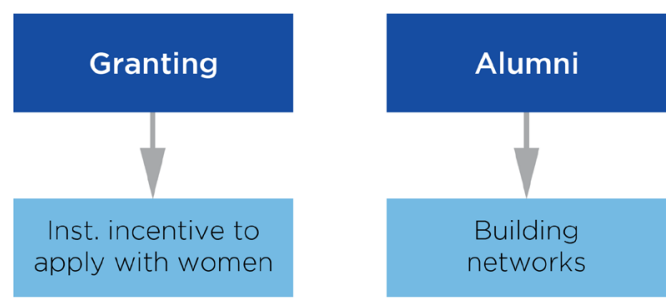

Consideration of unusual career path

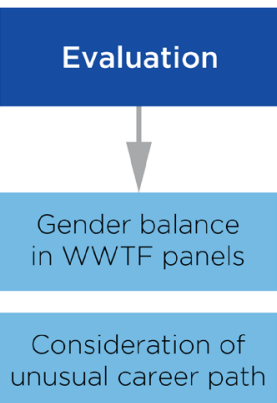



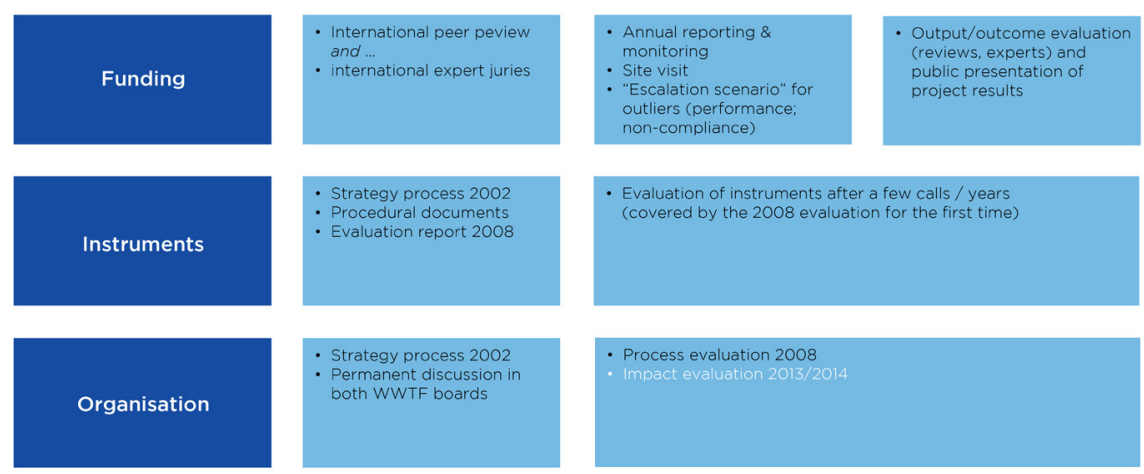

Figure 11: WWTF quality assurance matrix

\section{Quality assurance on the level of funding cases}

Quality assurance on the level of funding cases typically covers the "life cycle" of projects and person-oriented funding cases. Ex ante evaluations within competitive calls include a rigorous selection process that focuses on the quality of the applications. This process is managed by WWTF office and involves an international jury of renowned scientists and experts in the respective field which give a funding recommendation after an intensive discussion process which is based on 4 international reviews per proposal on average. This system shall prioritize quality and exclude local interests from decisionmaking process. Juries consist of 8-12 international scientists and experts ${ }^{8}$ (see also appendix with jury names). Note that WWTF switched recently from one stage to a two-stage application process with an even stronger jury involvement.

WWTF managed to get more than 3.200 review reports from international reviewers between 2003 and 2012. About 25\% of the reviewers are female, $75 \%$ are male. Based on the data we have access to, WWTF performs in terms of gender distribution of reviewers better than other funding agencies in the Austrian context, however, due to the different areas covered, the numbers are difficult to compare.
Interim quality assurance involves annual reporting on the progress of the project, financial monitoring and the reporting of outcomes and outputs such as publications, new cooperation links, career steps, industrial outreach and public outreach. The aim is to maximise the researchers' flexibility on the one side, and to get monitoring data to oversee the project success on the other side (and also to get data for mid-term and long-term statistics of the Fund itself). In rare cases of obvious poor performance and non-compliance with basic rules, WWTF can apply an "escalation scenario" to successively get deeper insights in the performance of the project to come to a well-informed decision on the continuation or the early termination of the project. Ex post evaluation of WWTF-funded activities are done on a regular basis, however, are not obligatory for all calls. It involves mechanisms of peer review to assess the quality of the outcomes of the project and to provide informed feedback to the projects in a setting that is open to the public. In a non-public part, the invited peers provide more general feedback to WWTF.

\section{Quality assurance on the level of instruments}

Quality assurance on the level of instruments goes beyond individual funding cases and aims to assess the fit and adequacy of the chosen instrument to reach the 
aims of the Fund and/or to assess the effects and impacts of the instrument. This level has a permanent component of feedback WWTF receives from experts and stakeholders in the boards and juries but also beyond (before, during and after individual calls) and a structured one, that is, commissioned studies (Edler 2007), and as part of evaluations (2008 evaluation and also this 2013 evaluation).

\section{Quality assurance on the level of the organisation}

Quality assurance on the level of the institution takes place in longer periods with regard to processes, programme priorities, administration, and impacts. These exercises target institutional learning processes to change and improve the institution's performance with regard to organisational structure, management, priorities and financing. So far, WWTF underwent such an evaluation exercise in 2008 on the processes and instruments of the fund, and now on its impacts.

The observation and assessment of outputs, outcomes and impacts are basically covered by two means: (1) Output and outcomes that result from funding cases are covered by the accompanying reporting and monitoring system. In preparation of this impact evaluation, WWTF harmonized the monitoring of the funding cases by building a more-structured online reporting system that both included past "offline" data but also provides a platform by which the funded persons report their outputs and outcomes in the future - and thus provide a unified database by which outputs and outcomes of WWTF-funded activities could be traced systematically. (2) Mid-term and long-term impacts, however, cannot be assessed by the means of standard reporting. Thus, WWTF Board of Directors has commissioned this impact evaluation.

\section{Supplementary activities of WWTF}

WWTF sees its additional activities as contribution to the impacts of the fund on the Viennese research and academic landscape. On the one hand, WWTF provides services for Viennese research institutions and thus helps enable a better interaction of them. On the other hand, WWTF often acts as interface between Viennese research institutions and local science policy (City Administration). The additional activities also contribute to a better understanding of the Viennese research and policy environment. Thus WWTF is able to deliver tailor-made funding activities which are of benefit for both research and policy in Vienna. Finally we provide consulting for customers abroad.

WWTF's main impact on the Viennese research landscape, researchers and institutions clearly comes from its main business of funding excellent research and researchers. This is the core of its activities by which WWTF seeks to be assessed by the Review Panel. However, WWTF is being involved in a number of activities both local and international that clearly bring in an added value for its core business of funding. The benefits that come from these activities are (1) an in-depth knowledge of the Viennese research landscape, its institutions and thus the needs of them (2) the capacity to act as a node in Vienna between in particular local STI policy and the research landscape but also (3) between research institutions in Vienna; and finally, (4) to be able to connect basic-oriented research in Vienna with broader issues of innovation in Vienna. In this regard, WWTF can selectively act as a "catalyser" in the Viennese context. 
- Dual Career Support Service: Commencing this fall, WWTF is providing support for Viennese research institutions in case of dual career couples. WWTF will act as independent contact point for supporting partners of new professors from abroad. These partners are in many cases also scientists and might find adequate positions in other institutions. So far, 13 institutions including major universities and research institutions in Vienna but also some institutions outside the city limits (e.g. IST-Austria in Lower Austria) are part of the network. This service aims to contribute to a more dense interaction between Viennese research institutions and to the (external) perception of Vienna as a common, integrated research area.

- WWTF is the host for two institutions: On the one hand, WWTF is the institutional home for the office of the current ERC president Prof. Helga Nowotny which provides a unique opportunity to stay in close touch with European activities and development in research. Helga Nowotny regularly provides advice in different matters when WWTF needs help. Connecting to the local, WWTF also hosts the City of Vienna commissioner for universities and research, Prof. Alexander van der Bellen, whose task is to improve the coordination between Viennese universities and the City of Vienna..$^{4}$

- WWTF carries out consulting projects (by way of its subsidiary WWTF GmbH) that relate to the wider innovation environment of Vienna and draws linkages to innovation policy and R\&D in companies. One pivotal project at the moment is the elaboration of a long term "Smart City" strategy for Vienna. Another project for the Vienna public utilities ("Wiener Stadtwerke AG", since 2010) shall help this large infrastructure provider in its innovation activities.

- Based on WWTF competences in scientific evaluation, WWTF is also supporting scientific institutions in Vienna through the organisation of evaluation processes.
- Furthermore, WWTF manages the University Infrastructure Programme of the City of Vienna through which the universities' municipal land tax is refunded by way of larger infrastructure projects. This programme is not competitive in its nature because only the rector's offices of the nine Viennese universities can submit a proposal. It helps to fill an important gap in the Austrian research context where sources to finance infrastructure are rather scarce. Since 2006 (and including the budget for 2013), more than $11 \mathrm{~m}$ Euro go to investments into Vienna university infrastructure.

- WWTF is centrally involved in activities to increase cooperation of Viennese research institutions (and R\&D intensive companies) with other areas within the European region around Vienna, including the vibrant location of Brno in the Czech Republic.

- WWTF is well-embedded in some relevant organisations and networks covering more general issues of science, research and innovation in the Austrian context. WWTF is member of the Platform Research \& Technology Policy Evaluation (fteval). ${ }^{10}$ Its mission is "to encourage more, better and more transparent evaluations for an optimal strategic planning of RTDpolicy in Austria and to develop a culture of evaluation together with decision-makers in the field of Austrian technology and research policy." Until recently WWTF hosted the office of the platform. WWTF is member and co-founder of the Austrian Agency for Research Integrity (OeAWI)," responsible for investigating alleged cases of scientific misconduct in Austria. Finally, WWTF is founding member of the Open Access Network Austria (OANA).12 Its mission is the coordination of and recommendations for the Austrian Open Access tasks and activities of the research institutions, funding organisations and research policies.

- The currently active RTDI strategy of the City of Vienna called "Wien denkt Zukunft. Wiener Strategie 
13 See http://www.iccr-foundation.org/projects/euro-coop

14 See: http://ec.europa.eu/enterprise/policies/innovation/support/ pro-inno/index en.htm
15 See http://erc.europa.eu/sites/default/files/document/file/eurecia_final_synthesis_report.pdf für Forschung, Technologie und Innovation" (Vienna thinks future) of 2007 was developed with strong WWTF involvement.

- So far, WWTF has been partner in three EU FP 6 and 7 Projects. (1) EURO-COOP: Regional Innovation Policy Impact Assessment and Benchmarking Process: Cooperation for Sustainable Regional Innovation. The main objective was to develop a research and innovation policy impact methodology at the regional levels. ${ }^{13}$ (2) INNO-DEAL focused on regional support programmes for innovative SMEs. ${ }^{14}$ (3) EURECIA - Un- derstanding and Assessing the Impact and Outcomes of the ERC and its Funding Schemes developed impact assessment measurements for the European Research Council ERC..$^{15}$ The latter led also to a number of publications.

- Finally WWTF (and WWTF GmbH) have provided studies and consulting to Federal Ministries, the EU Commission and notably to OECD - through three Country Innovation System Reviews (Switzerland, Slovenia, Sweden) in the last years.

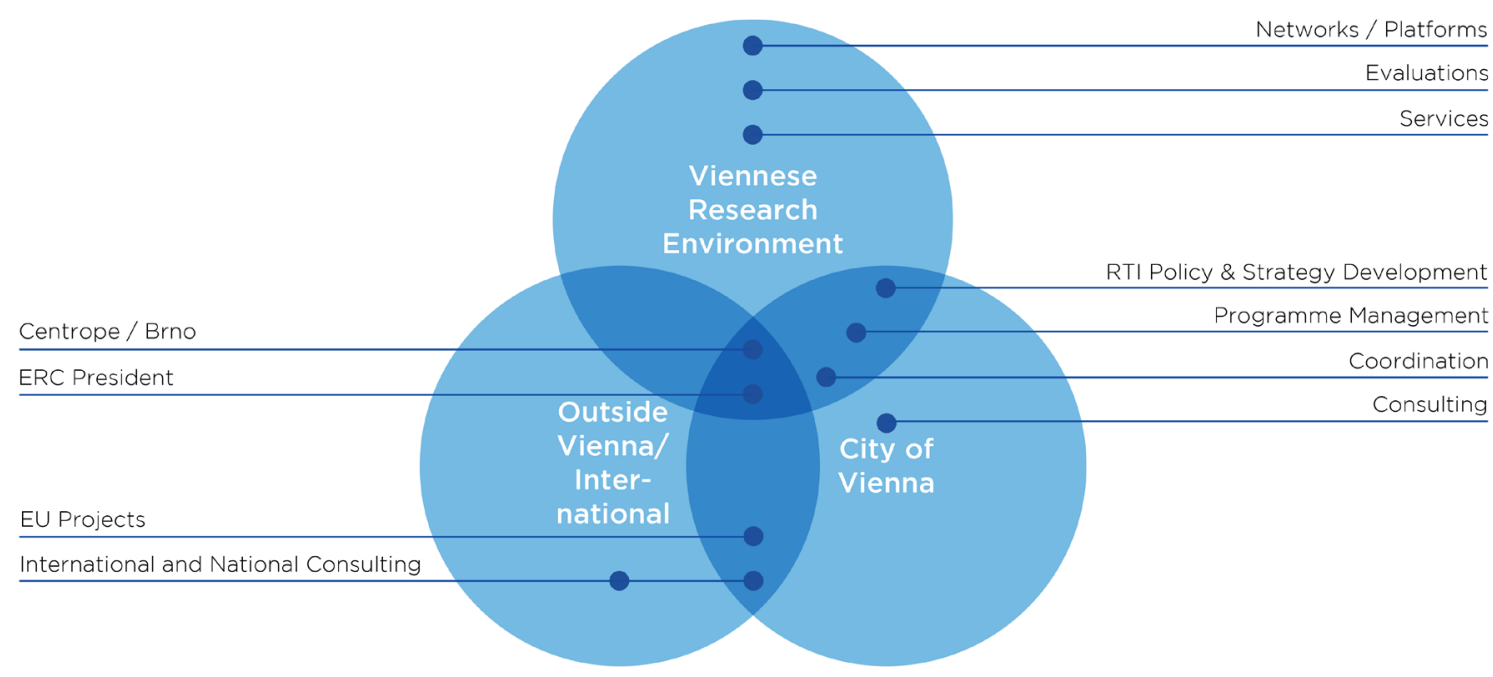





\section{The Austrian and the Viennese research and innovation landscape}

Austria's research underwent a catching-up process over the last two decades. The R\&D quota has been nearly doubled within this timeframe and now Austria is in the group of Innovation Followers (according to the Innovation Union Scoreboard, see European Commission 2013). There were large-scale structural reforms in the academic system leading to a more autonomous role of universities defining their agendas and supporting many areas of research in their catching up process with international developments and to develop a strong international position. Austria houses 22 public universities, thereof 9 in Vienna.

The Austrian GDP is 419b Euro. The projected 2013 R\&D expenditures in Austria are 8.96b Euro. R\&D quota (\% of GDP) in 2013 is $2.81 \%$. Over the last two decades, the country's R\&D sector was characterized by growth which was above European average with regard to its R\&D quota. Since 1991, Austria has been able to nearly double its R\&D quota. Austria was able to close ranks to the "Innovation Followers" (see Innovation Union Scoreboard 2013) and now aims to become an "innovation leader" until 2020 within the Federal R\&D strategy (see Republik Österreich 2011). Currently, however, Austria ranks 9th in the Innovation Union Scoreboard, after being already on rank 7 in 2011. This high amount of growth - including stagnation in the last years - can also be observed in the area of basic research for which the budget development of FWF is a good indicator. Over the last ten years, Austria was able to nearly double its (nominal) budget. Public spending for applied R\&D funding has seen an even more dynamic development over the last decade.

In particular within the last ten years Austria underwent a catching-up process in almost all areas of research. In many areas, research fields and research groups we find remarkably successful actors, however still not enough highest-cited researchers. In some areas (life sciences, quantum physics, but also a few others), a handful of institutions managed to become leading organisations on a global scale. This development is closely connected to institutional reforms triggered by a new University Law in 2002 and its successive implementation in the following years. Universities have become more independent from the Science Ministry and can make autonomous decisions in research and teaching. This contributed to a quite dynamic development of Austrian research over the last decade, a development which had started well before the 2000 s.

The local research development in Vienna reflects this more general trend. Furthermore, in some areas the development in Vienna has even been more dynamic as in the rest of Austria. Referring to the figures in the following table (see Table 10: R\&D key figures for Vienna and Austria (2011)), the number of R\&D units compared to the share of the overall population is significantly above the Austrian average- and so is the share of overall R\&D expenditures. While in the area of applied research the performance indicators of Styria and Upper Austria are better than those of Vienna, the city is the hot spot of scientific research in Austria. Vienna was able to increase FWF grant money by far more than the rest of Austria and now receives $62 \%$ of all funding of FWF. In total, $46.9 \%$ of all expenditures provided for basic research in Austria are given to Viennese research institutions.

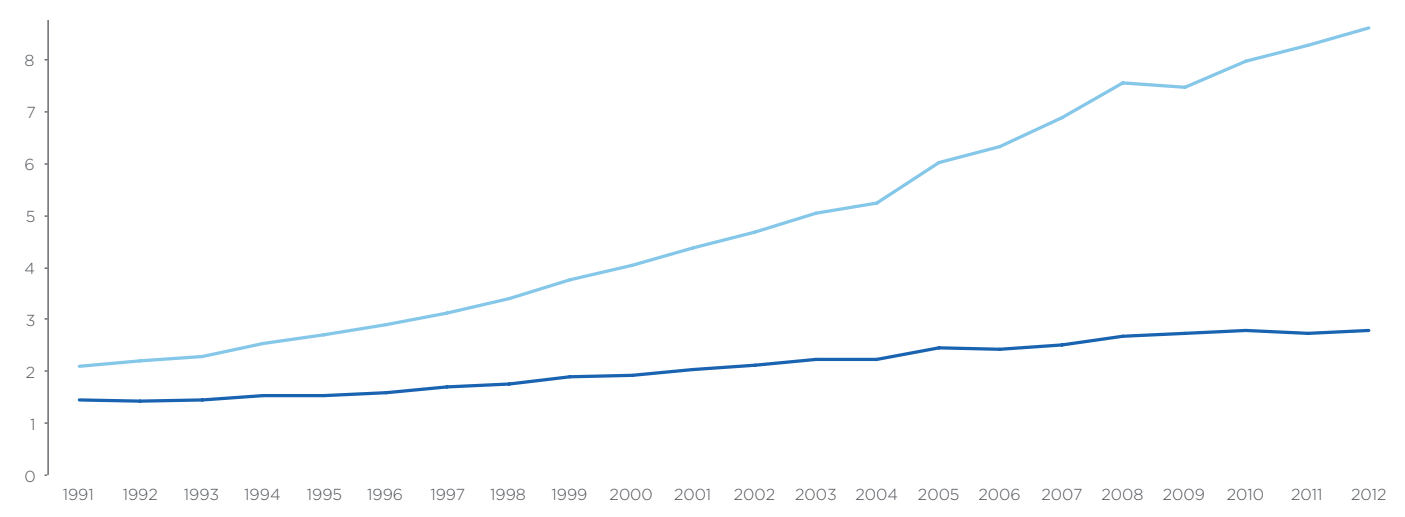

Figure 13: Expenditures in $m$ Euro (light blue) / R\&D quota in \% (dark blue) of GDP 1991-2012 in Austria Source. Statistik Austria GDP values until 2009 are definite, from 2010
und preliminary. 


\begin{tabular}{|c|c|c|}
\hline & Vienna & Austria \\
\hline \multirow[t]{2}{*}{ Population } & $1.75 \mathrm{~m}$ & $8.5 \mathrm{~m}$ \\
\hline & $20.6 \%$ & $100 \%$ \\
\hline R\&D quota (as of \% of GDP) & $3.4 \%$ & $2.77 \%$ \\
\hline \multirow[t]{2}{*}{ R\&D units (public and private) } & 1487 & 4984 \\
\hline & $29.8 \%$ & $100 \%$ \\
\hline \multirow[t]{2}{*}{ Overall R\&D expenditures } & $€ 2817 \mathrm{~m}$ & $€ 8126 \mathrm{~m}$ \\
\hline & $34.7 \%$ & $100 \%$ \\
\hline \multirow[t]{2}{*}{ thereof business sector } & $€ 971 \mathrm{~m}$ & $€ 3821$ \\
\hline & $25 \%$ & $100 \%$ \\
\hline \multirow[t]{2}{*}{ thereof public sector } & $€ 1382$ & $€ 3015$ \\
\hline & $45.8 \%$ & $100 \%$ \\
\hline \multirow[t]{2}{*}{ thereof private-non-profit sector } & $€ 23 \mathrm{~m}$ & $€ 39 \mathrm{~m}$ \\
\hline & $59.9 \%$ & $100 \%$ \\
\hline \multirow[t]{2}{*}{$\begin{array}{l}\text { thereof from foreign institutions } \\
\text { incl. EU and multinationals }\end{array}$} & $€ 494 \mathrm{~m}$ & $€ 1402 \mathrm{~m}$ \\
\hline & $31.3 \%$ & $100 \%$ \\
\hline \multirow[t]{2}{*}{ Expenditures basic research } & $€ 741 \mathrm{~m}$ & $€ 1577 \mathrm{~m}$ \\
\hline & $46.9 \%$ & $100 \%$ \\
\hline \multirow[t]{2}{*}{$\begin{array}{l}\text { Expenditures applied re- } \\
\text { search }\end{array}$} & $€ 1107 \mathrm{~m}$ & $€ 2907 \mathrm{~m}$ \\
\hline & $38.1 \%$ & $100 \%$ \\
\hline \multirow[t]{2}{*}{$\begin{array}{l}\text { Expenditures experimental } \\
\text { development }\end{array}$} & $€ 969 \mathrm{~m}$ & $€ 3642 \mathrm{~m}$ \\
\hline & $26.6 \%$ & $100 \%$ \\
\hline
\end{tabular}

Table 10: R\&D key figures for Vienna and Austria (2011) (Source: Statistik Austria)

\begin{tabular}{|c|c|c|}
\hline Name of University & $\begin{array}{l}\text { Federal } \\
\text { State }\end{array}$ & Scope \\
\hline $\begin{array}{l}\text { Akademie der bildendenden Künste } \\
\text { Wien } \\
\text { Academy of Fine Arts Vienna }\end{array}$ & Vienna & Fine arts \\
\hline $\begin{array}{l}\text { Medizinische Universität Wien } \\
\text { Medical University of Vienna }\end{array}$ & Vienna & $\begin{array}{l}\text { Medicine, } \\
\text { Life Scien- } \\
\text { ces }\end{array}$ \\
\hline $\begin{array}{l}\text { Technische Universität Wien } \\
\text { Vienna University of Technology }\end{array}$ & Vienna & Engineering \\
\hline $\begin{array}{l}\text { Universität für angewandte Kunst } \\
\text { Wien } \\
\text { University of Applied Arts Vienna }\end{array}$ & Vienna & $\begin{array}{l}\text { Applied } \\
\text { arts }\end{array}$ \\
\hline $\begin{array}{l}\text { Universität für Bodenkultur Wien } \\
\text { University of Natural Resources and } \\
\text { Life Sciences, Vienna }\end{array}$ & Vienna & $\begin{array}{l}\text { Life Scien- } \\
\text { ces }\end{array}$ \\
\hline $\begin{array}{l}\text { Universität für Musik und darstel- } \\
\text { lende Kunst Wien } \\
\text { University of Music and Performing } \\
\text { Arts Vienna }\end{array}$ & Vienna & $\begin{array}{l}\text { Performing } \\
\text { Arts }\end{array}$ \\
\hline $\begin{array}{l}\text { Universität Wien } \\
\text { University of Vienna }\end{array}$ & Vienna & $\begin{array}{l}\text { Disciplinary } \\
\text { comprehen- } \\
\text { sive }\end{array}$ \\
\hline $\begin{array}{l}\text { Veterinärmedizinische Universität } \\
\text { Wien } \\
\text { University of Veterinary Medicine, } \\
\text { Vienna }\end{array}$ & Vienna & $\begin{array}{l}\text { Life Scien- } \\
\text { ces }\end{array}$ \\
\hline $\begin{array}{l}\text { Wirtschaftsuniversität Wien } \\
\text { Vienna University of Business and } \\
\text { Economics }\end{array}$ & Vienna & $\begin{array}{l}\text { Business, } \\
\text { Economics }\end{array}$ \\
\hline $\begin{array}{l}\text { Universität für künstlerische und } \\
\text { industrielle Gestaltung Linz }\end{array}$ & Upper Austria & Arts \\
\hline $\begin{array}{l}\text { Universität Linz } \\
\text { University of Linz }\end{array}$ & Upper Austria & $\begin{array}{l}\text { Disciplinary } \\
\text { comprehen- } \\
\text { sive }\end{array}$ \\
\hline
\end{tabular}




\begin{tabular}{|c|c|c|}
\hline Name of University & $\begin{array}{l}\text { Federal } \\
\text { State }\end{array}$ & Scope \\
\hline $\begin{array}{l}\text { Medizinische Universität Innsbruck } \\
\text { Medical University of Innsbruck }\end{array}$ & Tyrol & $\begin{array}{l}\text { Medicine, } \\
\text { Life Scien- } \\
\text { ces }\end{array}$ \\
\hline $\begin{array}{l}\text { Universität Innsbruck } \\
\text { University of Innsbruck }\end{array}$ & Tyrol & $\begin{array}{l}\text { Disciplinary } \\
\text { comprehen- } \\
\text { sive }\end{array}$ \\
\hline $\begin{array}{l}\text { Medizinische Universität Graz } \\
\text { Medical University of Graz }\end{array}$ & Styria & $\begin{array}{l}\text { Medicine, } \\
\text { Life Scien- } \\
\text { ces }\end{array}$ \\
\hline $\begin{array}{l}\text { Montanuniversität Leoben } \\
\text { University of Leoben }\end{array}$ & Styria & Engineering \\
\hline $\begin{array}{l}\text { Technische Universität Graz } \\
\text { Graz University of Technology }\end{array}$ & Styria & Engineering \\
\hline $\begin{array}{l}\text { Universität für Musik und darstel- } \\
\text { lende Kunst Graz } \\
\text { University of Music and Performing } \\
\text { Arts Graz }\end{array}$ & Styria & Arts \\
\hline $\begin{array}{l}\text { Universität Graz } \\
\text { University of Graz }\end{array}$ & Styria & $\begin{array}{l}\text { Disciplinary } \\
\text { comprehen- } \\
\text { sive }\end{array}$ \\
\hline $\begin{array}{l}\text { Universität Mozarteum Salzburg } \\
\text { Mozarteum University Salzburg }\end{array}$ & Salzburg & Arts \\
\hline $\begin{array}{l}\text { Universität Salzburg } \\
\text { University of Salzburg }\end{array}$ & Salzburg & $\begin{array}{l}\text { Disciplinary } \\
\text { comprehen- } \\
\text { sive }\end{array}$ \\
\hline $\begin{array}{l}\text { Universität für Weiterbildung Krems } \\
\text { (Donau-Universität Krems) } \\
\text { Danube University Krems. Universi- } \\
\text { ty for Continuing Education }\end{array}$ & Lower Austria & $\begin{array}{l}\text { Continuing } \\
\text { education, } \\
\text { regulated } \\
\text { by an own } \\
\text { law }\end{array}$ \\
\hline Universität Klagenfurt & Carinthia & $\begin{array}{l}\text { Disciplinary } \\
\text { compre- } \\
\text { hensive but } \\
\text { no natural } \\
\text { sciences }\end{array}$ \\
\hline
\end{tabular}

Institutionally, there are 22 public universities in Austria (including one for further education currently not offering PhDs). Thereof, nine universities are located in Vienna. ${ }^{16}$ Thus, there's a great concentration of public universities in Vienna, including the University of Vienna (more than 90.000 students) which is by far the largest university in Austria (followed by the Vienna University of Technology, Karl-Franzens University in Graz and the University of Innsbruck with about 30.000 students each) Furthermore, Austria inhabits 21 Universities of Applied Sciences of which four are located in Vienna. ${ }^{17}$ There are compared to the international status many private universities in Austria but offering a rather limited number of postgraduate courses and are not engaged in major research activities.

Vienna is clearly the academic centre of Austria, as it houses nine of 22 universities and most of the sub-units of the larger extra-university research organisations (Austrian Academy of Sciences, AIT, Ludwig Boltzmann Institutes). About $60 \%$ of around 284.000 students in Austria study at Viennese universities.

About $79 \%$ of the awards for advanced researchers of FWF (Wittgensteinpreis) went to scientists at Viennese institutions, and $56 \%$ of the award for younger scientists (START-prize). Since the start of the ERC funding, "Austria" (that is researchers working at Austrian institutions) has received 101 grants from the European Research Council.18 68 of them went to Viennese institutions, that is $67 \%$. In particular areas, the percentage for Viennese institutions is even higher: In the life sciences, Vienna got $87 \%$ of all ERC grants that were given to the life sciences in Austria. ten/gesamtuebersicht/

17 See http://www.bmwf.gv.at/startseite/hochschulen/fachhochschulen/

18 Until September 2, 2013. Data: Federal Ministry of Science and Research. 


\begin{tabular}{|c|c|c|}
\hline Institution & Location & Scope \\
\hline $\begin{array}{l}\text { Austrian Academy of Sciences (Österrei- } \\
\text { chische Akademie der Wissenschaften) } \\
\text { Staff: } 1.300\end{array}$ & Dominantly in Vienna & $\begin{array}{l}\text { Departments / commissions in the Life Sciences, Natural } \\
\text { Sciences, and SSH }\end{array}$ \\
\hline $\begin{array}{l}\text { Austrian Institute of Technology - AIT } \\
\text { Staff: } 1.000\end{array}$ & $\begin{array}{l}\text { Locations distributed over } \\
\text { Austria, but main location } \\
\text { in Vienna }\end{array}$ & $\begin{array}{l}\text { Research and technological development in infrastructure } \\
\text { related technologies }\end{array}$ \\
\hline $\begin{array}{l}\text { Ludwig Boltzmann Gesellschaft } \\
\text { Staff: } 370\end{array}$ & Dominantly in Vienna & $\begin{array}{l}\text { Several Institutes in mainly the health sciences and in } \\
\text { history }\end{array}$ \\
\hline Christian Doppler Gesellschaft & $\begin{array}{l}\text { Located at existing } \\
\text { research institutions in } \\
\text { Austria }\end{array}$ & $\begin{array}{l}\text { Applied research at the interface to enterprises (technolo- } \\
\text { gy transfer), e.g. Life Sciences, many domains of enginee- } \\
\text { ring }\end{array}$ \\
\hline $\begin{array}{l}\text { International Institute for Applied Systems } \\
\text { Analyses (IIASA) } \\
\text { Staff: } 200\end{array}$ & Lower Austria & $\begin{array}{l}\text { Engaging with global problem areas such as energy, clima- } \\
\text { te, water, population dynamics }\end{array}$ \\
\hline $\begin{array}{l}\text { Institute of Science and Technology } \\
\text { Austria } \\
\text { Staff: quickly growing }\end{array}$ & Lower Austria, near Vienna & $\begin{array}{l}\text { Excellent basic research in many scientific areas, only } \\
\text { awarding PhDs }\end{array}$ \\
\hline Austrian Institute for Economic Research & Vienna & Economy and economic policy and related areas \\
\hline Institute for Advanced Studies & Vienna & Economics, political sciences, sociology \\
\hline
\end{tabular}

Table 12: Publicly-funded, extra-university institutions in Austria

Hence, Vienna is the location for scientific research in Austria, not only with regard to national competitors - it also houses a number of institutions that are internationally competitive. It would go far beyond the scope of this self-evaluation report to list all the departments and groups at Viennese universities which are considered on par with international competitors. To showcase an example, we refer to excellent life sciences institutions in Vienna, in particular to the Campus Vienna Biocenter, hosting 4 larger research laboratories (see table 13).

Outside the Campus, there are several institutions relevant in the life science domain, e.g., CeMM - Research Center for Molecular Medicine of the Austrian Academy of Sciences, BOKU/AIT location "Muthgasse" (Biotechnology, molecular diagnostics and nanobiotechnology), the large facilities and numerous groups of the Medical University of Vienna, the University of Veterinary Medicine, or the Vienna University of Technology. In sum, there are 25 life science research institutions in Vienna (see LISAvienna 2013), employing more than 14.000 people (half of them researchers) and more than 38.000 students.

\section{WWTF in the Austrian and regional funding landscape: Niche player}

In Austria, national R\&D funding is dominantly operated by two large agencies. The Austrian Science Fund FWF is responsible for the financial support of basic research (dominantly endowed by the Federal Ministry of Science and Research, annual budget 2012: 180 m Euro) and the Austrian Research Promotion Agency FFG (dominantly endowed by the Federal Ministry for Infrastructure, annual budget 2012: $482 \mathrm{~m}$ Euro). This means, the budget for applied R\&D project funding is 2.7 times the budget for those in basic research.

Besides federal funding of R\&D, federal states also invest in this area, however to a different degree. If done to a larger extent, R\&D funding in federal states dominantIy takes place in the area of applied $R \& D$, but rarely on science in a more basic sense. WWTF, thus, is by far the largest regional funding organisation in Austria investing in scientific research, however, compared to the overall actors, the fund is a real niche player.

\begin{tabular}{|c|c|}
\hline IMP (The Research Institute of Molecular Pathology) & $\begin{array}{l}\text { owned and largely sponsored by the pharmaceutical company Boehringer } \\
\text { Ingelheim }\end{array}$ \\
\hline IMBA (Institute of Molecular Biotechnology) & for basic molecular biology research of the Austrian Academy of Sciences \\
\hline GMI (The Gregor Mendel Institute) & for basic plant research also of the Austrian Academy of Sciences \\
\hline MFPL (Max F. Perutz Laboratories) & joint venture of University of Vienna and Medical University of Vienna \\
\hline
\end{tabular}




\begin{tabular}{ll}
\hline Institution & Budget 2013-2015 \\
\hline University of Vienna & $€ 1118 \mathrm{~m}$ \\
\hline Medical University of Vienna & $€ 946 \mathrm{~m}$ \\
\hline Vienna University of Technology & $€ 650 \mathrm{~m}$ \\
\hline University of Innsbruck & $€ 564 \mathrm{~m}$ \\
\hline University of Graz & $€ 501 \mathrm{~m}$ \\
\hline Technical University Graz & $€ 375 \mathrm{~m}$ \\
\hline University of Salzburg & $€ 335 \mathrm{~m}$ \\
\hline Medical University of Graz & $€ 329 \mathrm{~m}$ \\
\hline
\end{tabular}

Table 14: University budgets 2013 - 2015 (selection)

Besides WWTF, the R\&D policy in Vienna is shaped by a number of regional actors. The main funding organisations for R\&D in Vienna are ZIT (Center for Innovation and Technology) and "departure", both subsidiaries of the "wirtschaftsagentur wien" (Vienna Business Agency). ZIT, founded in 2000, promotes R\&D for innovation and technology in industry and businesses through various instruments and has an annual budget of $11 \mathrm{~m}$ Euro for ZIT funding programmes and related activities. "departure" was founded 2004 and provides funding for the creative industry in Vienna. WWTF, ZIT and departure act complementary to each other

As mentioned above, WWTF receives a large proportion of its budget from a private banking foundation and is itself an independent public, non-profit fund. This constellation is quite unique in Austria, where private persons or organisations rarely support scientific research (as for example compared to Switzerland, Sweden or Germany).

\section{Addendum}

Insert of information required by the review panel during the evaluation process.

\section{Financial situation of Austrian universities}

The Austrian Science Fund (FWF) granted a total of 196.4 $\mathrm{m}$ Euro in 2012. Of that, $97.6 \mathrm{~m}$ Euro went into
19 See Österreichischer Forschungs- und Technologiebericht 2013 http://www. bmvit.gv.at/innovation/publikationen/ richt2013.pdf see in particular p. 48.

20 See http://www.snf.ch/SiteCollectionDocuments/por_fac_sta_kurz_jb12_d.pdf, p. 29

21 Until September 2, 2013. Data: Federal Ministry of Science and Research.

22 See http://www.bmvit.gvat/innovation/ publikationen/technologieberichte/ downloads/ftbericht2013.pdf p.53 funding of bottom-up research projects, the remaining financial means went in diverse research programmes (person funding, research prizes, networks). ${ }^{19}$ FWF received a slight increase of budget ( $0.6 \%$ compared to 2011), but the number of applications increases at a higher rate with the effect that the rate of the proposal that are funded is de-creasing from $30.6 \%$ (2011) to $30.2 \%$ in 2012. As a comparison, the Swiss National Fund (SNF) is funding $54 \%$ of all projects which applied for funding. ${ }^{20}$ FWF granted 684 new projects in 2012 (Swiss NF granted 1206 new projects in 2012). What university receives what amount of money is made public via the annual "Wissensbilanz" of the universities. ${ }^{21}$ E.g. the University of Vienna received $38.1 \mathrm{~m}$ Euro from FWF in 2012.

The second national research funding agency is the FFG. It is responsible for funding applied R\&D and had a budget for funding of $481 \mathrm{~m}$ Euro in 2012. Universities can apply for this money together with industry partners. They received $11 \%$ of this budget that is $39.7 \mathrm{~m}$ Euro in 2012. ${ }^{22}$

Funding of universities: The Federal Science Ministry and the 22 Austrian universities nego-tiate performance agreements for a three year period (current period is 20132015). See the following figure for an overview: E.g. the University of Vienna received 1.118 b Euro for the three years from the ministry, which is an $15 \%$ increase since the last period 2010-12 and a $34 \%$ increase since period 2007-2009

\begin{tabular}{lrrr}
\hline Institution & Annual budget $(b €)$ & No. of students & Budget/student $(€)$ \\
\hline Harvard University & 2.9 & 21.000 & 161.000 \\
\hline Stanford University & 2.7 & 16.000 & 196.000 \\
\hline UCA Berkeley & 1.7 & 36.000 & 55.000 \\
\hline MIT & 2.0 & 11.000 & 211.000 \\
\hline ETH Zurich & 1.2 & 18.000 & 47.000 \\
\hline University of Zurich & 1.0 & 26.000 & 27.000 \\
\hline Technical University of Munich & 1.1 & 35.000 & 32.000 \\
\hline University of Munich & 1.0 & 50.000 & 21.000 \\
\hline Vienna University of Technology & 0.3 & 28.000 & 11.000 \\
\hline University of Vienna & 0.5 & 92.000 & 5.000 \\
\hline University of Innsbruck & 0.2 & 28.000 & 7.000 \\
\hline University of Graz & 0.2 & 31.000 & 6.000
\end{tabular}

Table 15: Comparison: Annual budget / student (2012, adjusted for purchasing power) 



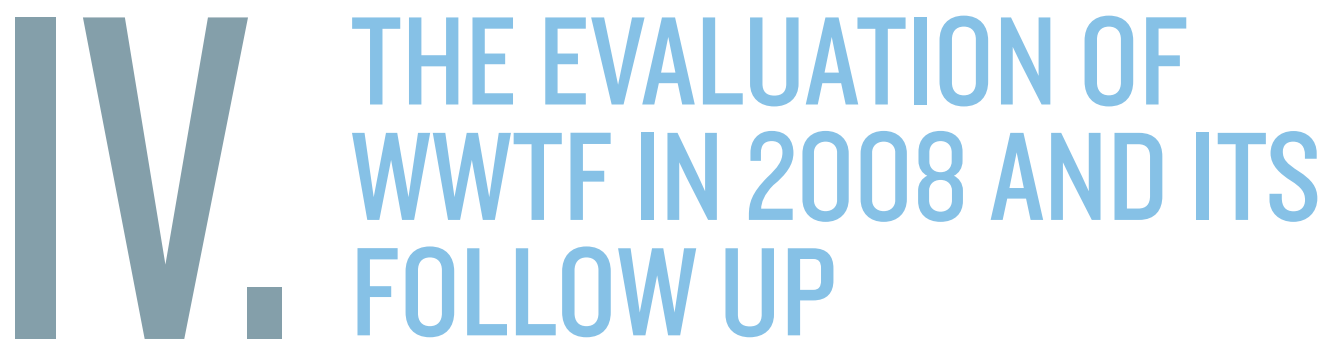

\section{Aim and content of the 2008 evaluation}

In 2008, an international review panel consisting of the life scientists Prof. Angelika Amon (Cambridge, US), Prof. Fritz Bach (Harvard, US, ${ }^{+2011)}$ ), the social scientist Prof. Jakob Edler (Manchester, UK), the life scientist Prof. Ole Fejerskov (Aarhus, DK), Prof. Dorothy Guy-Ohlson (Stockholm, SE), secretary general of Volkswagenstiftung Wilhelm Krull (Hanover, Germany, Chair) was commissioned to evaluate WWTF. The panel was asked to assess the success of instruments and funding mechanisms of WWTF with regard to the following key issues:

- WWTF setup and strategy

- Defining and pursuing topical funding areas

- Funding instruments including WWTF science chairs

- Procedures and project selection

- First results and perspectives

- Excellence vs. relevance?

- The way ahead - Perspectives and organisational recommendations

Overall assessment of the Review Panel:

"The WWTF has succeeded remarkably well in building up an independent and successful research funding organisation, in establishing competitive professional processes, and in already having a decisive impact on carefully selected areas of the Viennese research landscape."

\section{Recommendations of the 2008 Review Panel and their implementation}

\section{Independency and driver of change}

R1 "The WWTF should continue its path as an independent highly focused organisation to further enhance its impact" ... "We strongly encourage the WWTF to continue to take on a leading role in facilitating change in the Viennese research system."

WWTF continued by maintaining its independence and by keeping its focus on selected areas, targets and instruments. We also pursued the goal of driving change in the Viennese research landscape.

\section{New international scientific advisory board}

R2 "An international scientific advisory board whose main task it is to identify new possible funding areas visà-vis international developments and opportunities in the Viennese research landscape should be established."

WWTF did not take up this recommendation for various reasons. WWTF has two boards defined in its statutes (Board of Directors and Advisory Board) and a third board would double competences, raise administrative costs and overcommit WWTF office by the organisation of board meetings (several WWTF board meetings, three juries a year, etc.). However, in the forefront and aftermath of calls, international scientists (often members of prior or current juries) with expertise in the field are involved to provide guidance in the design of new calls or to give feedback on the further development of the thematic priorities after calls have ended. Seen from that perspective, WWTF has not one standing international scientific advisory board, but a worldwide advisory network. 


\section{New programme priorities}

R3 "WWTF constantly needs to address new and emerging fields, ... however, there are issues with regard to the tension between continuity and reliability in building capacity versus the constant need for thematic innovation." ...

"Within the panel there were mixed feelings regarding this development to move into information technologies and translational medical research: The WWTF should not leave an area and go into new fields until critical mass has been built up. As mentioned above, instead of moving too fast into new areas, one could think of building on the success of the first funding waves, e.g. through support of additional activities."

WWTF is very carefully balancing the new with continuation, e.g. demonstrated by the CS priority. In 2008, a science chair in that area was subject to a call, and in 2011 it became a programme priority. WWTF abandoned one priority in the past, the rather unfocused "Science for Creative Industries" Programme. We are also aware not to step in the fashion trap by following scientific hypes that are not sustainable but we open doors to innovations and newness by inner-thematic foci, e.g. addressing translational research from bench to clinics in two LS calls or by allowing for more risky, interdisciplinary projects in the 2013 LS call. The all-new 2008 ICT programme so far received overwhelming positive feedback by the involved programme juries (3 project calls and 1 VRG so far) as well as by the Vienna scientific community. Many projects could account for excellent publication successes so far. In this programme, many early stage researchers have been funded and provided considerable boost to their careers. The translational medical research call (LS 2007 and 2011) only recently underwent an ex-post and interim evaluation through an evaluation day (September 2013) again with very positive feedback by the invited international experts. There is great demand in the Viennese research community for funding this type of research.

\section{Refocus of priority areas}

R4 "WWTF should keep its interdisciplinary focus". ... "Out of the present priority areas, the "Mathematics and..." calls had the strongest impact and appear to be to be most promising. The "Life Sciences" and "Creative Industries" calls seem to have been rather broad in their topical definition. To take account for the need of critical mass and competition in Vienna on the one hand and to make a difference, to create visible foci on the other hand, the WWTF should consider continuing these priority areas in a more focused way."

WWTF continued its commitment to interdisciplinarity, in particular in Life Sciences 2013 call, in the Mathematics and ... programme, in the Cognitive Sciences or in the SSH programme. We also issued more focussed calls in the Life Sciences area (Translational research between lab bench and clinics; highrisk/high gain projects); Creative Industries was re-focussed to a Cognitive Sciences priority.

\section{Long-term funding of early stage researchers}

R5 "The WWTF plays a crucial role in facilitating the recruitment of excellently qualified early stage researchers with high potential to Vienna. In order to ensure the sustainability, however, the grants for these young researchers need to be more long-term. The WWTF could distinguish between grants for established researchers and young researchers coming in (e.g. a 3 +2 years solution) and allow for more flexibility to renegotiate prolongation."

Over the last 4 years, WWTF put great emphasis on the careers of early stage researchers in particular by introducing the instrument of the Vienna Research Groups that fulfils the recommendation of being long-term (6 to 8 years). The greater flexibility to renegotiate prolongation of the career possibilities of early stage researchers was reached by the contractual 
obligation to the institution to offer a permanent position after a positive evaluation. The recruitment of established researchers was accomplished by science chair calls.

WWTF also extended the time a project could be prolonged. Originally, it has been $1 / 6$ of the planned length, now, the standard is $1 / 4$ which means that a four year project can be stretched to five years. Beyond that, PIs can (and they already have done so) prolong their project if they can reasonable argue it.

\section{Interface between WWTF and universities}

R6 "The interface between WWTF and the universities with regard to employment and treatment of young researchers needs to be formalized and made clear upfront. Expectations need to be managed, and clear contractual situations regarding infrastructure, administrative support, and integration have to be negotiated and signed before payments are made and projects start. The WWTF should be prepared to stay involved in the early phases of a new researcher's settling into his/her position in Vienna to assure that the expectations on both sides are met."

The improvement of the interface to the Viennese research institutions (not only the universities) is a constant effort of WWTF as well as the management what WWTF is expecting from the institutions with regard to what they offer to the researchers. This was done partly in a structured way by engaging the institutions in a continued discussion process on these issues and partly in a formalized way by the design of contractual relationships. For example, group leaders in the VRG programme receive contracts that involve tenured positions putting them in a better situation than most of their peer group colleagues. WWTF is also partly involved in the early phases of a new researchers' career setting by mediating between the researchers and the institutions. Furthermore, in contract negotiations for projects, WWTF emphasizes the importance of young researcher career development as reflected in their contractual situation within the project. However, WWTF is aware that today research institutions need to accommodate manifold interests when managing careers of their staff.

\section{Science Chairs}

R7 "The WWTF should consider offering two different types of Science Chairs for young researchers as well as for leading scholars in their fields. Ways have to be found to overcome the legal issues regarding the Science Chairs. If this instrument is to be a long-term sustainable success, it has to be ensured that they are smoothly operating and provide a real perspective for young scientists. For each chair funded a clear up-front commitment by the Viennese universities is needed."

"'Five-Star' Chair: this would be an opportunity for Viennese universities to attract established researchers. ... Only if the university provides full professorship ... is the University eligible for application."

"Incoming" positions for young researchers were established by the VRG programme by which the young academics immediately become Assistant Professor and, after an evaluation step, Associate Professor. Ways to overcome the legal issues regarding the Science Chairs could not been found - and are not seen in the near and distant future as WWTF is highly depending on the legal situation in this regard. The performance of the Science Chair is, good: 3 Science chairs have become full professors anyway, 2 have permanent positions and full professor applications are under way in these cases. Two smaller Science Chair funding slots were given with the universities in charge of the selection process.

How to proceed? The question remains, should WWTF in case of continuation of Science Chair funding switch to another model or continue as we did until 2008? The "Five-Star" chairs are still an open issue and up to now it is unclear how to proceed. The 2008 Review Panel already raised concerns about the commitment of the university scene in this issue.

Overall, important steps have been accomplished for group leaders in the VRG programme where institutions must give a clear upfront career commitment as a pre-condition for application. 


\section{Focus on Scientific Excellence}

R8 "The panel wishes to encourage the WWTF to keep its clear focus on scientific excellence. The existing mid-term relevance should be kept, but should be understood by WWTF as a consequence of excellence, whereby relevance stems from the structural effects on the Viennese science landscape in its entirety and the selection of adequate topics and persons rather than just some form of knowledge transfer into application."

WWTF kept the focus on a few, well-defined topics. Since 2008, only Cognitive Sciences was made a thematic priority formally (but was already present by a 2008 Science Chair call). WWTF clearly maintained its focus on scientific excellence which is reflected by the conditions of calls and the composition of the international juries. The focus on scientific excellence and the following structural effects on the Viennese research landscape is a cornerstone for this impact evaluation (see Terms of Reference) as this is a key issue by which WWTF's impact shall be assessed.

\section{Impact Assessment}

R9 "Accordingly, the WWTF should continue to focus on indicators for excellence, not on short term measurable results. The impact assessment in 5 years from now should therefore not be based solely on input/output indicators, but rather on quality of people, career and group development, attraction of young talent, development of targeted areas."

Realized by the Terms of Reference and the methodological setup of the current 2013 impact evaluation.

\section{Monitoring}

R10 "Monitoring needs to be improved: contractual agreements should provide a framework for real monitoring in terms of integration, general working conditions, administrative support and scientific progress. Rules and targets need to be specified and agreed upon in advance to ensure that the project starts operating early."

WWTF reworked monitoring after the 2008 evaluation in a first step by developing new forms which incorporate the issues mentioned by the review panel. The monitoring and reporting obligations of grantees are defined in the contract. In preparation of the 2013 impact evaluation, the hitherto offline monitoring was put online and further improved. WWTF took care, however, that monitoring did not become an aim in itself and thus not putting both great administrative burden on the researchers and the fund.

\section{Joint Workshops}

R11 "The joint workshops with all projects funded within a call are really productive: they allow for an exchange of ideas, identifying new opportunities for collaboration, sharpening the focus of individual projects, and for networking in Vienna. The WWTF should make increased use of this instrument and strive at including those workshops in the roadmaps of the programmes funded."

Joint workshops are currently done within the ex-post evaluation process at the "evaluation days" (see above chapt. II.6.). This is well received by both the invited experts who provide comments and the researchers in the projects. Further various joint workshops have been organised along topics as "Gender" and "Intellectual Property Rights". 


\section{Programme management and administrative costs}

R12 "With regard to internal processes, the panel recommends separating controlling and programme management. This is a question of good governance...

At present, given the lack of economies of scale due to its limited size, the overhead management structures of the WWTF are lean, representing $7 \%$ of the total budget, If, however, the WWTF were to even more actively manage an even larger number of programmes in the future, increased management capacity and size will become inevitable, thus necessitating a considerable rise in management costs."

WWTF operatively separated these two areas of management, however, both areas act in tight coordination. Given the increase of programmes and projects to be managed, the overhead management structures could be kept lean, representing 7-8\% of the total budget.

\section{Management of City of Vienna Programmes}

R13 "Some caution is also needed with regard to the planned call in the humanities on behalf of the City of Vienna: the WWTF needs to be aware of the fact that acting as an agency for other funders with public money will be dangerous to its profile and reputation as an independent research funding organisation. Therefore, the procedures need to be defined very carefully and similar to WWTF rules. On the other hand, it is certainly a proof of success, that the city of Vienna entrusts public money to a private foundation."

The warnings of the review panel have up to now not proven to be true. Both the SSH and the VRG programme are funded by the City of Vienna and could be realized by WWTF's own terms and conditions. The City of Vienna appreciates WWTF as an independent actor warranting that the process and the selection is done at highest international standards and by no other means than in WWTF's own programmes. WWTF has done rightly in making no procedural difference between its own and city programmes but has used public money for clearly separate funding initiatives. Furthermore, by managing these programmes, WWTF was able to better communicate the benefits of independent research to the city authorities. 



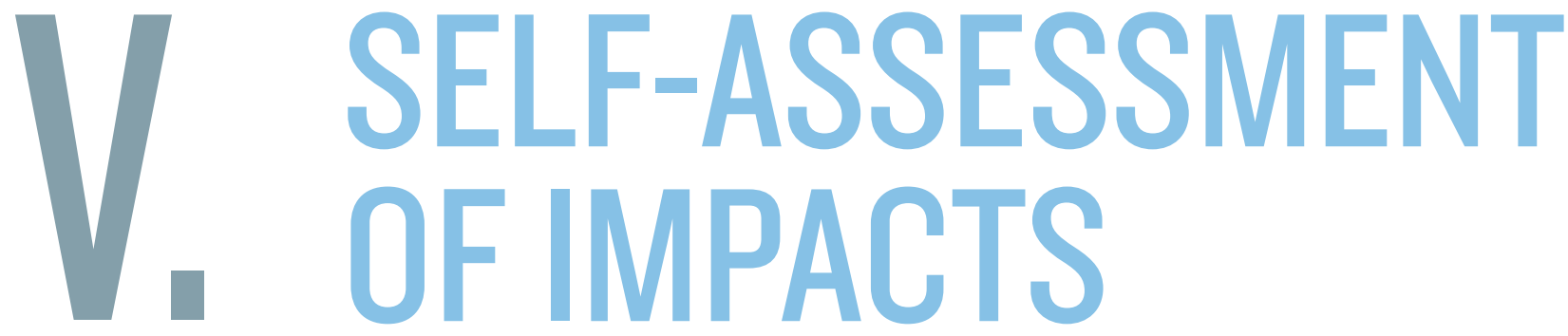

Helga Nowotny, the president of the European Research Council, has emphasized on many occasions that "one only recognizes excellence when you encounter it". And what she has stated for scientific excellence is transferable to the assessment impacts of research. Both excellence and impacts cannot be defined in an abstract way but need to take into consideration its contexts. And to assess both, quantitative indicators should be used in a modest way as they often do not cover the question what is quality in a sufficient way.

Hence, we are rather cautious to offer accumulated and average numbers of publications and of other output. While publications are directly attributable outputs, the question of their wider impact is much harder to answer. Advanced bibliometric analyses in order to assess this matter could not reasonably be done within the financial constraints of this evaluation and still would have left open many questions on the quality of the outputs, plus creating interpretative problems due to small numbers. Furthermore, WWTF is funding research in five different areas that have rather different publication traditions and thus 5+ different ways to assess the quality of outputs. Cutting across these fields, e.g. SSH and ICT, and calculating average numbers would not make any sense. But within the fields themselves, the number of funded projects is actually not that great since many of them are still running. For example, out of 32 funded ICT projects, only 11 have been finished so far. As the programme aims to be unique within the Austrian context there are no reference values at all and therefore, it is rather costly and complex to do a serious, indicator based analysis. So, if we dare to do provide numbers on the following pages, they have to be interpreted cum grano salis.

Hereafter we want to cover the six areas of impact (see also Terms of Reference for this evaluation) where we think that WWTF is unfolding effects. They are not understood as mutually exclusive but should be indicative on what areas a funding organisation might be relevant. These six areas (see Figure 14: Impact areas) are people (= researchers), their research, Viennese research institutions, the topics and fields covered by WWTF funding priorities, the communities of researchers within these areas and the more broader environment/ context in Vienna. Several aspects are covered by the Case Study of Grit Laudel, on other aspects WWTF provides a selfassessment and some more aspects need to be covered by the group interviews at the review panel meeting.

\section{Impacts on "People"}

In our monitoring process, all principal investigators of funded projects are supposed to report on career steps of people involved in their WWTF projects. While there is a large number of career items accounted for - from BA to full professors or even positions outside academia, they were not pre-categorized before we introduced our new online reporting system. So that available data are not consistent in order to analyse them straightforward. Furthermore, this kind of information has not been asked for from project leaders funded by the very first calls of WWTF.

We can observe that within different research areas, researchers of different age and on different career levels are applying for funding at WWTF. E.g, in SSH, for the calls that covered more established topics such as "migration", it was typically an established professor who

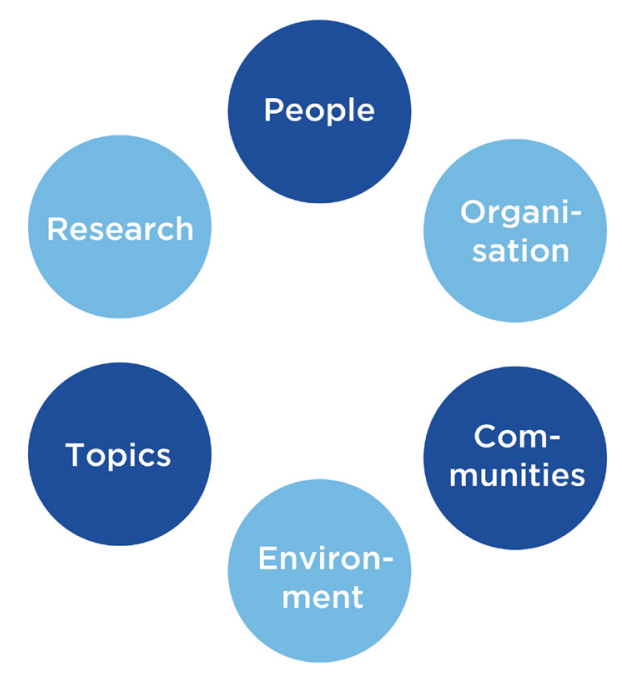


submitted a proposal together with some PhDs or one to two PostDocs as collaborators. Hence, not too many high ranked career steps on the way to become a full professor can be expected in the SSH because project collaborators either already have one or are really early stage researchers Each field has also its own idiosyncrasies in the ways, career developments are accomplished, which makes it difficult to compare across different areas. Secondly, the responsibility to report ends when the project is finished. Thus, we have no complete data set on career steps taken after the completion of projects. However, even if WWTF funding contributes to the reputation of a researcher so that she or he finally receives a professorship, it is rather unlikely that this happens during the project period or shortly afterwards. Due to financial restrictions of all universities a substantial growth of academic positions, in particular professorships, cannot be expected for the time being. Hence, institutions often cannot offer long-term commitment in terms of employment and career assurances. Against this backdrop WWTF initiated the Vienna Research Group programme to tackle some of the problems addressed. While on the one hand traditional career patterns were reinforced through a tenure-track-like system installed in Austria commencing 2004, career paths simultaneously become more diversified through the involvement of extra-university research institutions that employ more diversified and flexible career development patterns. Thus, criteria for successful research careers have diversified making it more complex to measure success in a uniform and standardized way. In this sense, all numbers WWTF provides have to be read in a cautious way.

From the data available, ${ }^{23} 33$ persons who worked in WWTF projects received a permanent position at a university (either as Associate Professor or as Full Professor). However, about 50\% received their professorship outside Austria thus leaving the Viennese home institution. There is a number of cases where Viennese insti- tutions just were not able to make an attractive offer in order to keep excellent people here. On the other side, there are successful examples where WWTF helped to start a career in Vienna. Thomas Klausberger, for example, came to Vienna through the Science Chair Call 2008 on Cognitive Sciences and since 2011 he is professor at the Department of Neurobiology of the Medical University of Vienna (he is also Head of Department and received an ERC grant). Other examples are people like Andrea Pichler or Florian Kiefer who successfully applied for a WWTF project from abroad and then came to Vienna.

A typical final report of a project lists 2-4 career steps of PIs and collaborators beyond PhD phase.

In order to assess WWTF's impact on people and their careers another indicator should be looked at: What kind of other grants have been given to WWTF funded researchers? Again, our monitoring does only cover the duration of the project but does not track developments afterwards. From data in our monitoring system we know that WWTF funded researchers received quite a number of grants, both nationally (in particular FWF grants) and internationally. Thereof ERC grants as an indicator for quality are of special interest.

With regard to ERC grants, the performance of Viennese host institutions is excellent compared to most other regions in Austria (see above, chapter III.3.). Out of 68 ERC grants received by Viennese institutions, 19 are connected to WWTF funding (see Table 17: WWTF and ERC grantees). For the assessment of the impacts of WWTF activities only those cases are of interest where the grantee received an ERC grant after (or at least at the same time of) a WWTF grant. This applies for 18 of the 19 cases. Out of these, 8 persons were involved in WWTF project as project partners, 10 persons had been principal investigators. While attribution of cause and effect in case of fundraising is a non-trivial task and would need 
much deeper investigation, we would like to point out two WWTF-funded persons. Both, Thomas Klausberger (MUW) and Chris Oostenbrink (BOKU), came to Viennese institutions from abroad by the means of WWTF funding and then received the ERC grant.

For further impacts on people and their career we are referring to Grit Laudel's case study.

\section{Impacts on "Organisations"}

Such impacts are very difficult to track for WWTF. Definitely our Science Chairs and Vienna Research Groups are interesting models (and sometimes role models) for career development at Vienna universities. Vienna Research Groups have very clear career paths (to Associate Professor positions) often better than "normal" careers (for Science Chairs see Edler 2007, WWTF 2008). Whether these models lead to institutional learning is difficult to assess for us: WWTF is small, career track discussions are Byzantine in Austria, and positive developments are always invented by the research organisations themselves.

Regarding projects, WWTF has started with funding overheads in 2003 and grants a $20 \%$ flat rate (in the case of the Social Sciences and Humanities it is even up to 30\%). WWTF has been consistent in its overhead policy throughout its beginning in 2003 and was a pioneering actor in this context. Furthermore, our clearly structured contracts strike a balance between dealing professionally with the home organisations while granting the Pls a high degree of freedom. Both simplicity and clarity of customer relations are WWTF assets.
The following figure shows in more detail how research money of WWTF programme priorities is institutionally distributed. Compared to the overall third-party funding income for R\&D the universities can draw from, the proportion of WWTF funding is relatively small. For example, the University of Vienna received $76.7 \mathrm{~m}$ Euro for R\&D in 2012 - WWTF contributed to this only with $4.4 \%$. The proportion for the Vienna University of Technology is quite similar: WWTF contributed $5.5 \%$ to the total of 71.7 m Euro.

However, an "economy of scale" of WWTF funding can be assumed in some areas at some universities, e.g. the ICT domain at the Vienna University of Technology. VUT has been the most successful institution in absolute numbers in WWTF ICT calls, by now (2008-today) receiving more than $11 \mathrm{~m}$ Euro only from this funding programme. In year 2012 VUT received about 11 m Euro in total in the ICT domain (including not only basic research but all R\&D projects), thereof about $2.4 \mathrm{~m}$ Euro came from WWTF for ICT projects. Hence, in this special area, WWTF funding can be substantial. However, the WWTF ICT programme is not running long enough yet to be able to observe visible effects on that field at the VUT and beyond.

\section{Impacts on "Communities"}

WWTF contributed to the growth, the orientation and the growing together of fields. With regard to growth visible effects come with the size of grants and the concentration on funding a few fields in Vienna over a longer time: More talented people can evolve, come to Vienna or stay here for next career steps. Due to the rather broad formulation of many WWTF calls strong fields and

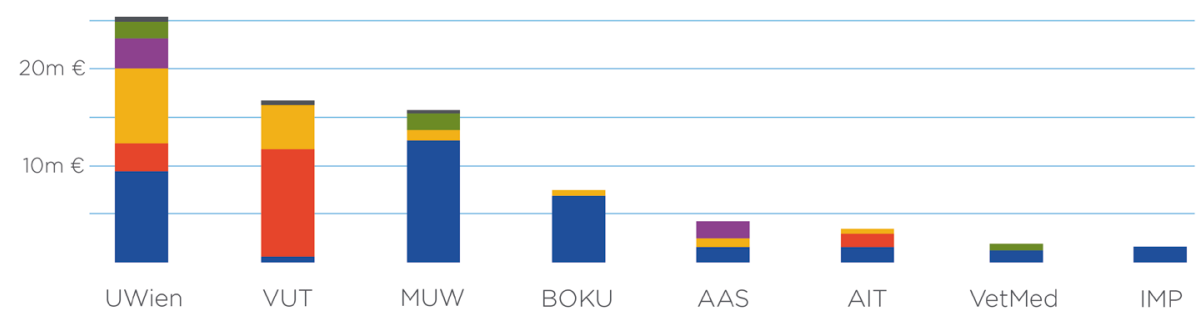


strong groups are supported not by top down selection but through bottom up competitions. With regard to orientation the two funding priorities "Mathematics and ..." and "ICT" can serve as examples for specific WWTF interventions with approx. $20 \mathrm{~m}$ Euro in each field over a number of years: In Mathematics, the challenge is to strengthen the more applied approaches and the formation of strong interdisciplinary linkages with other fields. In ICT the challenge is exactly the opposite: While third party funding for applied projects with industry collaboration is abundant in Austria (FFG, competence centres etc.) and on EU-level, proper funding of more fundamental projects is insufficient, and the same is true for career opportunities.

With regard to linkages between fields WWTF funding has helped to build a number of interesting bridges. Examples include biomathematics, bioinformatics and other links between biosciences and natural sciences. Further WWTF funding helped to better establish Viennese strongholds and networks in mobile telecommunications research, animal cognition or evolutionary biology.

\section{Impacts on "Environment"}

WWTF has introduced a number of new initiatives in the Austrian landscape: We were first in tackling the issues of funding art based research and scientific research in the context of creative industries with Art(s) \& Sciences Calls 2008 and 2009 and with Science for Creative Industries Calls 2003 and 2006. We pioneered focussed funding for translational clinical research with the Life Sciences Call on "Linking Research and Patients' Needs" 2007 and 2011. Cognitive Sciences got a boost through WWTF $(2008,2011,2013)$ as well as applied interdisci- plinary mathematics through various calls since 2004. Some WWTF funding initiatives might have influenced discussions in other funding organisations.

WWTF Science Chairs were quite an innovation in Austria (see again 2008 evaluation). A similar federal initiative ("Stiftungsprofessuren Produktionsforschung") could be started in 2013 by the help of WWTF consulting. The incoming programme "Vienna Research Groups" is a singular initiative in Austria. Only recently, a similar scheme was started by the Austria Academy of Sciences called "New Frontiers Group" however without competition between different institutions (only Academy of Sciences institutes can apply).

A central criterion in many WWTF calls is the mid- to long-term economic and societal benefit of the research. Here we are strictly following our own mission and strategy as well as the recommendations of the 2008 review panel which stated:

The existing mid-term relevance should be kept, but should be understood by WWTF as a consequence of excellence, whereby relevance stems from the structural effects on the Viennese science landscape in its entirety and the selection of adequate topics and persons rather than just some form of knowledge transfer into application. (p. 5)

Hence, the scientific quality and relevance always comes first - which is expressed in our procedures in particular peer review and jury processes by scientists. We aim to contribute to an innovation-friendly environment in which in particular the essential role of basic research in providing sustainable resources for more applied forms of R\&D is emphasized. While this is often neglected in national science policy discourses, wide evidence is available that only those nations whose investments in scientific research are substantial can act as innovati- 
on leaders. These effects are always long-term and not always directly attributable to institutions of small size (see also Laudel 2013, 32).

Our monitoring data provide some information about industrial outreach of the projects we funded. Again, project leaders only report those activities that came into being during the project runtime. So far, they indicated 44 cooperation activities with various industrial actors, including local and international enterprises in the areas of Life Sciences, ICT and also Mathematics. 16 out of the 44 cooperation came into being in the area of Mathematics which can be seen as a good success of the programme aiming at bridging Mathematics to (potential) applications. There were also 10 patent applications reported, mostly by Life Sciences researchers. Furthermore, the foundation of three companies has been associated to WWTF funded projects; all three of them in the ICT domain. However, direct causalities are surely overstated as nobody starts a company based solely on a scientific project.

\section{Impacts on "Topics"}

As there is a large overlap of this area with "Communities", this has already been addressed in article 3. Impacts on "communities".

\section{Impacts on "Research"}

We have made a disclaimer at the beginning of this chapter as to being very modest in using statistics and bibliometrics of the research output in order to assess the impact of funded projects. Despite that we will provide and discuss some numbers:

\section{Information and Communication Technology}

As this is a rather young WWTF programme, only about $1 / 3$ of the funded projects have been finished so far (11 of 32) and thus have reported on their total outputs. This is represented by the numbers: Projects funded by the Call 2008 (all finished except one) produced 332 publications; projects of the Call 2010 reported 144 publications so far; and last year's call (projects began late 2012 and not all projects have delivered their annual report so far) reported 19 publications by now. For the nearly finished projects of the 2008 Call the average number of publications is about 28 whereas the absolute number of publications varies between 10 and 45 . However, we have no indication that the project with only 10 publications is of lower quality than others.

Figure 16 illustrates the balance between different types of publications hinting to the great importance of conference contributions in the area of ICT.

61 journal papers have been produced out of these projects and a high number is peer-reviewed (56). Yet, the ICT programme covers a wide range from activities including software and hardware development. Thus, different forms of publication formats are relevant in different areas of ICT and (invited) conference contributions play a big role here.

\section{Social Sciences and Humanities in Vienna}

A judgement on the output (publications) of this programme is even more difficult than in the ICT domain. Firstly, within five calls, three different subthemes of SSH have been covered. The first two calls addressed projects at the interface of SSH and the arts which is not (and particularly was not at that time) a well-defined and developed field in Austria. The two calls in a way pioneered the field in Vienna and therefore, the range of funded

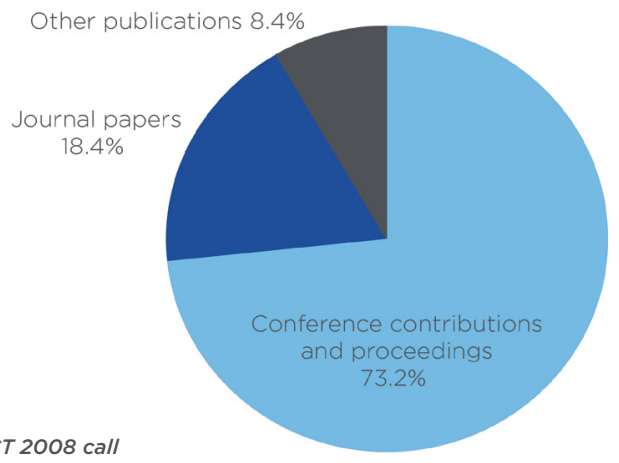


projects was rather wide: from those in which art (performances) played a central role to rather classical social sciences projects. The publication channels in different SSH disciplines and the arts are very diverse - journal papers, monographs, exhibitions \& performances, conference contributions, online publications, etc. The small number of internationally peer-reviewed journal publications reported should be stressed. The number of publications produced within a single project varies to a great degree, from a handful to over hundred. Overall, publication formats that include ways of quality assurance are scarce. This is, however, rather typical for the SSH landscape in the Austrian context which is characterized by a fairly low degree of internationalisation and by the use of a publication format without quality assurance. However, on 27 September 2013, all the projects have been assessed at an evaluation event by international experts. The overall quality of the project was seen as good with a few internationally excellent projects.

SSH Calls 2010 and 2011 addressed more traditional topics - diversity, identity, issues of migration - and targeted a more established community within given disciplines such as political sciences, linguistics, sociology, history, demography and alike. Hence, the publication output is not that heterogeneous as in the previous calls. However, only one project has been finished by now (i.e. having submitted the final report). Therefore, a statistical overview would be of no value here. Among the reported output there is a great share of conference contributions (65\%); $12 \%$ are peer-reviewed journal papers (10 in total, of which are 9 in English-language journals). Since the 2011 Call projects have only delivered their first annual report by now many more publications are to be expected. What we can observe is that within the SSH the number of publications in internationally peer-reviewed journals has been increased over the last years.
As we do not have numbers of comparable areas outside WWTF, any judgement based on numbers is problematic.

\section{Mathematics and ...}

So far, there have been three calls within the domain of Mathematics and ... resulting in 29 funded projects. Of the 2009 call only two projects have been finished yet; thus numbers are still preliminary in this regard. The overall publication output of these three calls is 1001, that is an average of 35 publications per project. The output number of the 2007 call projects is substantially higher than those of the 2004 call (44 to 31). The number of peer-reviewed articles from all calls is 274 . However, any qualification if these numbers feature high quality (again: compared to what) cannot be stated by WWTF office.

\section{Life Sciences}

Commencing 2003 there have been 8 projects calls in this domain. The calls of 2012 and 2013 are not included in the statistics as funded projects do not have reported yet. Due to late beginning in 2012 and some reporting delays it is too early for the projects of the 2011 call on translational research to the clinics to include output numbers in here that are not significant. Taking into consideration all projects from 2003 to 2007, 614 publication output items have been produced; this is an average of 19 publications per project. However, the different calls vary to a high degree: the average of the 2005 call on Molecular Methods was 15, while the call 2007 on translational research produced 26 publications on average.

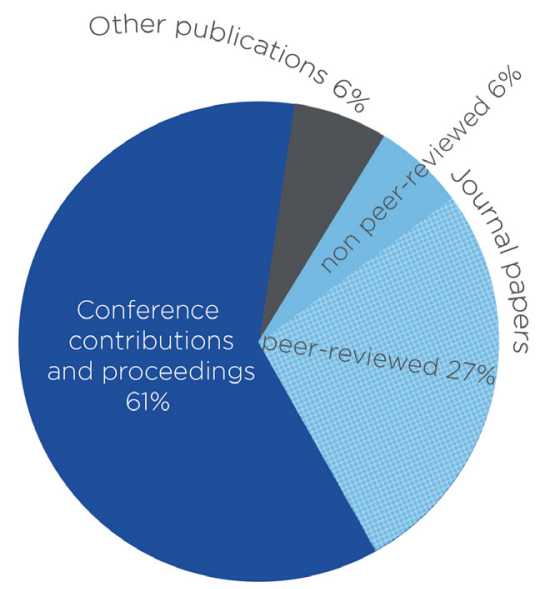


Figure 18: Example for an acknowledgement of funders in a scientific paper of a WWTFfunded researcher

A. Tedeschi et al. 2013. Wapl is an essential regulator of chromatin structure and chromosome segregation. Nature 501, 564-568 (26 September 2013).

There are many high level publications stemming from WWTF funded projects, including numerous publications in Nature, Science or Cell, as well invitations to high level conferences. Some very recent examples are (only PIs that are funded by WWTF are indicated):

Jan-Michael Peters, Alipasha Vaziri et al. 2013. Wapl is an essential regulator of chromatin structure and chromosome segregation. Nature 501, 564-568.

Alipasha Vaziri et al. 2013. Brain-wide 3D imaging of neuronal activity in Caenorhabditis elegans with sculpted light. Nature Methods 10, 1013-1020.

Philip Walther et al. 2013. Experimental verification of quantum computation. Experimental verification of quantum computation. Nature Physics.

Claus Lamm et al. 2013. Right Supramarginal Gyrus Is Crucial to Overcome Emotional Egocentricity Bias in Social Judgments. The Journal of Neuroscience 33(39):15466 -15476.
Acknowledgements We dedicate this paper to the memory of B. Peters, who performed the first experiments on Wapl in our laboratory. We are grateful to K. Aumayr, O. F.-Capetillo, T. Hoffmann, M. E. Idarraga-Amado, S. Kueng, T. Kulcsar, M. Leeb, P. Pasierbek, D. Santamaria, G. Schmauss, A. Souabni, H. Tkadletz, K. Wendt and members of the Peters laboratory for discussions and assistance, J. Hutchins for suggesting the term vermicelli, K. Nasmyth for the separase mouse model, and M. Barbacid, T. Cremer, T. Hirano, T. Jenuwein, M. Malumbres and J.Zuber for reagents, T.N. was supported by the European Molecular Biology Organization (EMBO) and the Japanese Society for the Promotion of Science (JSPS). S. H. Was supported by funds
from the Agence National de la Recherche (JCJC-SVSE2-2011, ChromaTranscript project) and the European Union (FP7-PEOPLE-2011-CIG, ChromaTranscript project). D.A.C. was supported by MFPL VIPS Program (BMWF and City of Vienna). A.V. acknowledges financial support by the Vienna Science and Technology Fund (WWTF) project VRG10-11, the Research Platform Quantum Phenomena and Nanoscale Biological Systems (QuNaBioS) and by Boehringer Ingelheim. Research in the laboratory of J.M.P. is supported by Boehringer Ingelheim, the Austrian Science Fund (FWF special research program SFB 34 'Chromosome Dynamics, and Wittgenstein for Optimized Structural Studies), the Vienna Science and Technology Fund (WWTF LS09-13), and the European Community's Seventh Framework Programme (FP7/ 2007-2013) under grant agreement no. 241548 (MitoSys).
As mentioned above in the "Impacts on environment" section, causal effects are real difficult to attribute. Even in the simple case of scientific papers, attribution is a tricky issue, as the (typical) example from a Nature publication of a WWTF funded project demonstrates. WWTF is among many others who needed to be acknowledged. We do not consider this as a bad example of attributing acknowledgement but as a good example demonstrating how research works today.

Measuring the impact of publications is an on-going discussion where the consensus is that applying simple metrics (e.g. relying on the Journal Impact Factor) is not sufficient to assess the quality of the research. To do an assessment of publication impact of WWTF funded researchers by the means of a quantitative analysis is way beyond the possibilities and the scope of this evaluation. We refer to the San Francisco Declaration of Research Assessment ${ }^{24}$ which recommends a broad range of impact measures including qualitative indicators. WWTF in this regard relies on the judgement of peers both in ex ante and ex post evaluation where publications of researchers are qualitatively judged in a group of experienced experts.

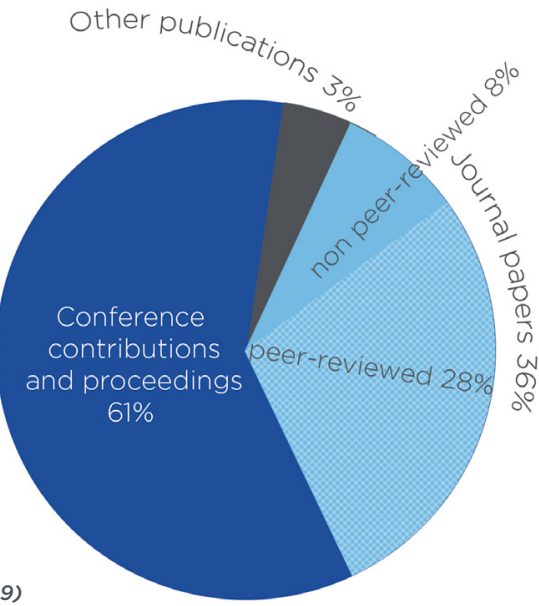




\section{Strengths and Weaknesses / Opportunities and Threats}

- Knowledge of the local research environment in Vienna and strong international links and networks

- Ability to pursue long term missions,

- Reliability and flexibility / sensibility towards context

- Innovativeness (new instruments, programmes ...), fast mover if necessary

- Organizational independence and excellent relation to city government and administration

- Mission driven by underlying values of scientific quality

- Non-bureaucratic, non-formalistic; but nonnegotiable quality standards

- Funding + ... (consultancy): Best of both worlds

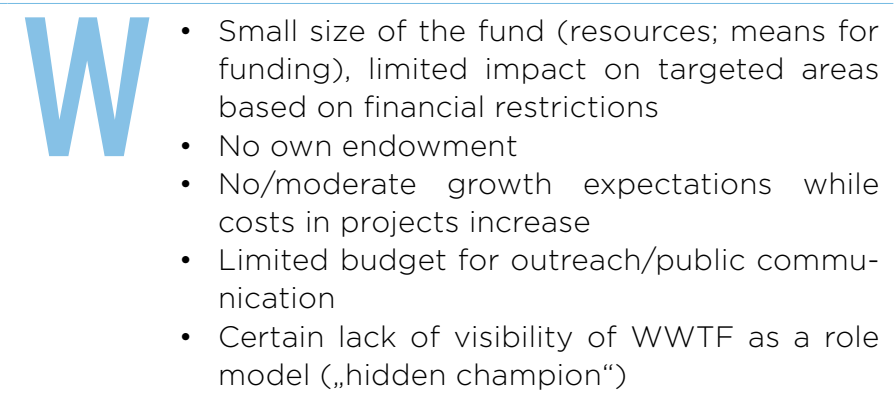
model (,hidden champion“)
- Quality rise of Austrian science over the last 10 years or so

- Concentration of scientific institutions in Vienna; strong position of some research fields (e.g. Life Sciences); strong or emerging fields or combinations grow

- Increased demand for interfaces between scientific research and enterprises/political administration, etc.

- Increased demand for "commons" in the research context in Vienna, e.g. expertise that goes beyond the research funding business

- Relatively strong interest of local government in science, R\&D
- Institutional environment sending many, sometimes conflicting signals; drift of the Austrian innovation system towards symbolic actions and lack of will to solve structural problems

- Lack of institutional collaboration in Vienna

- Tendency of the environment to delegate problems to WWTF

- Reluctance - due to financial restrictions - to invest on the side of research institutions

- Epistemic and structural conservatism within parts of the research environment 


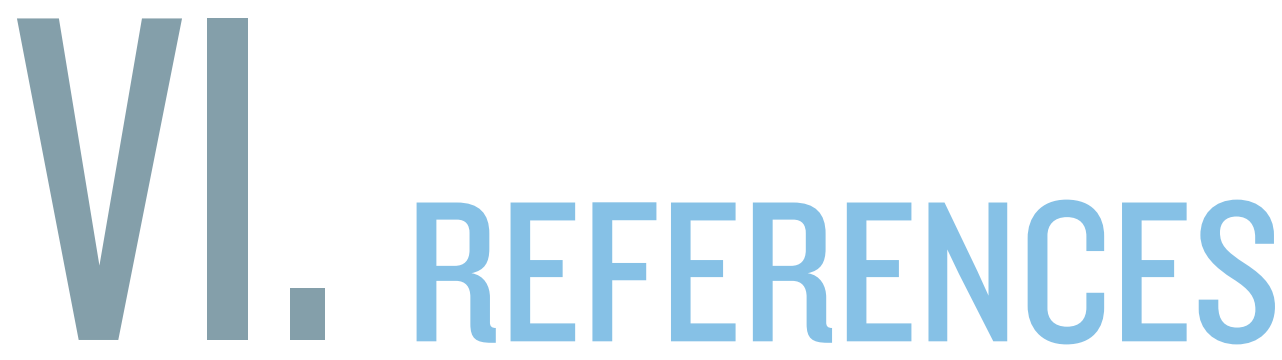

Edler, J. 2007. Assessment des Instruments der Stiftungsprofessuren des Wiener Wissenschafts-, Forschungsund Technologiefonds am Beispiel der Bioinformatik.

European Commission. 2013. Innovation Union Scoreboard 2013. European Union.

FWF. 2007. Der Wettbewerb der Nationen - oder wie weit die österreichische Forschung von der Weltspitze entfernt ist. Eine Analyse der internationalen Wettbewerbsfähigkeit wissenschaftlicher Forschung Österreichs in den Natur- und Sozialwissenschaften. Wien, Oktober 2007.

Laudel, G. 2013. An in-depth case study of selected WWTF impacts. Technical University Berlin, Institute of Sociology. Berlin, October 2013.

LISAvienna. Life science austria. 2013. Vienna Life Science Report 2013/14. Wien.

Republik Österreich. 2011. Der Weg zum Innovation Leader. Strategie der Bundesregierung für Forschung, Technologie und Innovation.
Stadt Wien. 2007. Wien denkt Zukunft. Wissen schafft Innovation. Wiener Strategie für Forschung, Technologie und Innovation.

Technopolis \& Fraunhofer ISI. 2006. Life Science - Standort Wien im Vergleich. Endbericht im Auftrag MA 27 EUStrategie und Wirtschaftsentwicklung. Wien, Jänner 2006.

Wirth, M. 2013. Der Campus Vienna Biocenter. Entstehung, Entwicklung und Bedeutung für den Life SciencesStandort Wien.

WWTF (Wiener Wissenschafts-, Forschungs- und Technologiefonds) 2002. Hintergrund- und Strategiepapier für Aufbau, Aufgaben und Funktionsweise des WWTF (by Michael Stampfer and Gerald Murauer).

WWTF (Wiener Wissenschafts-, Forschungs- und Technologiefonds) 2008. Enhancing WWTF's Impact on the Viennese Research Landscape - Perspectives for the Next Five Years. Report by the International Review Panel, April 2008 



\section{VI, APPENDICES}

\section{List of members of WWTF boards / office by mid 2013}

\begin{tabular}{|c|c|}
\hline \multicolumn{2}{|c|}{ Members of the WWTF Board of Directors } \\
\hline Michael Häupl & $\begin{array}{l}\text { President of WWTF, Governor of } \\
\text { the City of Vienna }\end{array}$ \\
\hline Stephan Koren & $\begin{array}{l}\text { Vice president of WWTF, CEO } \\
\text { Österreichische Volksbanken AG }\end{array}$ \\
\hline Heinz W. Engl & Rector of the University of Vienna \\
\hline Gerhard Mayr & $\begin{array}{l}\text { Chairman of the Board, UCB S.A. } \\
\text { and Former Executive VP of Eli } \\
\text { Lilly and Company }\end{array}$ \\
\hline Renée Schroeder & Full Professor, University of Vienna \\
\hline Franz Zwickl & $\begin{array}{l}\text { Member of the Board of Directors } \\
\text { of Foundation Privatstiftung zur } \\
\text { Verwaltung von Anteilsrechten }\end{array}$ \\
\hline \multicolumn{2}{|c|}{ Members of the WWTF Advisory Board } \\
\hline Thomas Oliva & $\begin{array}{l}\text { Chairman, former director of } \\
\text { Viennese branch of the Federation } \\
\text { of Austrian Industry }\end{array}$ \\
\hline $\begin{array}{l}\text { Melitta } \\
\text { Aschauer-Nagl }\end{array}$ & Austrian Chamber of Labour \\
\hline Christoph Badelt & $\begin{array}{l}\text { Rector of the Vienna University of } \\
\text { Economics and Business }\end{array}$ \\
\hline $\begin{array}{l}\text { Hermann } \\
\text { Bürstmayr (until } \\
\text { Fall 2013) }\end{array}$ & $\begin{array}{l}\text { Professor, University of Natural } \\
\text { Resources and Life Sciences }\end{array}$ \\
\hline
\end{tabular}

\begin{tabular}{|c|c|}
\hline \multicolumn{2}{|c|}{ Members of the WWTF Advisory Board (cont.) } \\
\hline $\begin{array}{l}\text { Christoph } \\
\text { Dellago }\end{array}$ & Professor, University of Vienna \\
\hline $\begin{array}{l}\text { Otto Doblhoff- } \\
\text { Dier }\end{array}$ & $\begin{array}{l}\text { Vice-Rector, University of } \\
\text { Veterinary Medicine Vienna }\end{array}$ \\
\hline $\begin{array}{l}\text { Hubert Christian } \\
\text { Ehalt }\end{array}$ & City of Vienna \\
\hline $\begin{array}{l}\text { Johannes } \\
\text { Fröhlich }\end{array}$ & $\begin{array}{l}\text { Vice-Rector, Vienna University of } \\
\text { Technology }\end{array}$ \\
\hline $\begin{array}{l}\text { Josef Glößl } \\
\text { (since Fall 2013) }\end{array}$ & $\begin{array}{l}\text { Vize-Rector, University of Natural } \\
\text { Resources and Life Sciences }\end{array}$ \\
\hline $\begin{array}{l}\text { Sonia } \\
\text { Hammerschmid }\end{array}$ & $\begin{array}{l}\text { Rector, University of Veterinary } \\
\text { Medicine Vienna }\end{array}$ \\
\hline $\begin{array}{l}\text { Hans Robert } \\
\text { Hansen }\end{array}$ & $\begin{array}{l}\text { Professor (em.), Vienna University } \\
\text { of Economics and Business, } \\
\text { Foundation Privatstiftung zur } \\
\text { Verwaltung von Anteilsrechten }\end{array}$ \\
\hline $\begin{array}{l}\text { Markus } \\
\text { Hengstschläger }\end{array}$ & $\begin{array}{l}\text { Professor, Medical University of } \\
\text { Vienna }\end{array}$ \\
\hline Andreas Hoeferl & $\begin{array}{l}\text { SPÖ - Social Democratic Party of } \\
\text { Austria }\end{array}$ \\
\hline $\begin{array}{l}\text { Erika Jensen- } \\
\text { Jarolim }\end{array}$ & $\begin{array}{l}\text { Professor, Medical University of } \\
\text { Vienna }\end{array}$ \\
\hline Cornelia Kasper & $\begin{array}{l}\text { Professor, University of Natural } \\
\text { Resources and Life Sciences }\end{array}$ \\
\hline $\begin{array}{l}\text { Josef } \\
\text { Kramhoeller }\end{array}$ & City of Vienna \\
\hline Gottfried Magerl & $\begin{array}{l}\text { Professor, Vienna University of } \\
\text { Technology }\end{array}$ \\
\hline $\begin{array}{l}\text { Eberhard } \\
\text { Nachbagauer } \\
\text { (until Fall 2013) }\end{array}$ & $\begin{array}{l}\text { Foundation Privatstiftung zur } \\
\text { Verwaltung von Anteilsrechten }\end{array}$ \\
\hline
\end{tabular}




\begin{tabular}{|c|c|}
\hline \multicolumn{2}{|c|}{ Members of the WWTF Advisory Board (cont.) } \\
\hline $\begin{array}{l}\text { Helmut } \\
\text { Naumann }\end{array}$ & $\begin{array}{l}\text { WKO - Austrian Economic } \\
\text { Chambers, Vienna Branch }\end{array}$ \\
\hline $\begin{array}{l}\text { Herbert Pichler } \\
\text { (since Fall 2013) }\end{array}$ & $\begin{array}{l}\text { Foundation Privatstiftung zur } \\
\text { Verwaltung von Anteilsrechten }\end{array}$ \\
\hline Arnold Schmidt & $\begin{array}{l}\text { Professor (em.), Vienna University } \\
\text { of Technology, former President } \\
\text { of FWF }\end{array}$ \\
\hline Karl Sigmund & $\begin{array}{l}\text { Professor, University of Vienna; } \\
\text { former Vice-President FWF }\end{array}$ \\
\hline Barbara Sporn & $\begin{array}{l}\text { Vice-Rector, Vienna University of } \\
\text { Economics and Business }\end{array}$ \\
\hline Roman Stiftner & Austrian Economic Chambers \\
\hline $\begin{array}{l}\text { Alexander van } \\
\text { der Bellen }\end{array}$ & Die Grünen - Green Party \\
\hline Alfred Wansch & FPÖ - Freedom Party of Austria \\
\hline $\begin{array}{l}\text { Susanne } \\
\text { Weigelin- } \\
\text { Schwiedrzik }\end{array}$ & Vice-Rector, University of Vienna \\
\hline
\end{tabular}

\section{Current employees of WWTF office}

\begin{tabular}{ll}
\hline Michael Stampfer & Managing Director \\
\hline Donia Lasinger & Programme Manager \\
\hline Cornelia Schrauf & Programme Manager \\
\hline Michael Strassnig & Programme Manager \\
\hline Alexander Wöhrer & Programme Manager \\
\hline Marita Benkwitz & Controlling \\
\hline Gerda Adam & Backoffice \\
\hline Silvia Benes & Backoffice \\
\hline
\end{tabular}

\section{Past employees of WWTF office}

Daniela Former Programme Manager, now Head

Frischer of Graduate Funding, McGill University, Canada

Michaela Former Programme Manager, now Head

Glanz Project Service of the Academy of Fine Arts Vienna

Michael Former Programme Manager, now Head Hofer of Quality Assurance, University Vienna

Gerald Former Vice-Managing Director, now Murauer Head of Corporate Technology CEE Siemens Austria

Klaus Former Vice-Managing Director, now

Zinöcker Consultant at Austrian Science Fund FWF 


\section{WWTF funded persons and national / international awards}

\begin{tabular}{|c|c|c|c|c|c|}
\hline Name & Institution & PI or Partner & Yr WWTF grant & Yr ERC grant & WWTF area \\
\hline Barry Dickson & IMP & Partner & 2005 & 2008 & LS \\
\hline Jürgen Knoblich & IMBA & $\mathrm{PI}$ & 2005 & 2009 & LS \\
\hline Walter Schachermayer & UWien & $\mathrm{PI}$ & 2004 & 2009 & MA \\
\hline Alexander Stark & IMP & Partner & 2009 & 2009 & LS \\
\hline Thomas Klausberger & MUW & PI (Science Chair) & 2008 & 2009 & LS \\
\hline Markus Aspelmeyer & UWien & $\mathrm{PI}$ & 2012 & 2009 & ICT \\
\hline Adrian Constantin & UWien & $\mathrm{PI}$ & 2009 & 2010 & MA \\
\hline Thorsten Schumm & VUT & Partner & 2007 & 2010 & MA \\
\hline Chris Oostenbrink & Chris Oostenbrink & PI (Science Chair) & 2008 & 2010 & LS \\
\hline Meinrad Busslinger & IMP & Partner & 2009 & 2011 & LS \\
\hline Michael Wagner & UWien & $\mathrm{PI}$ & 2003 & 2011 & LS \\
\hline Christian Schlötterer & VetMed & Partner & 2004 & 2011 & MA \\
\hline Andrew Straw & IMP & $\mathrm{PI}$ & 2011 & 2011 & CS \\
\hline Tomas Sobootka & AAS & Partner & 2010 & 2011 & SSH \\
\hline Hannes Schmiedmayer & VUT & Partner & 2007 & 2012 & MA \\
\hline Sebastian Nijman & CeMM & $\mathrm{PI}$ & 2009 & 2012 & LS \\
\hline Friederike Range & VetMed & Partner & 2011 & 2012 & CS \\
\hline Monika Henzinger & UWien & $\mathrm{PI}$ & 2010 & 2013 & ICT \\
\hline Holger Rauhut & RWTH Aachen, former UWien & $\mathrm{PI}$ & 2004 & 2010 & MA \\
\hline
\end{tabular}

Table 17: WWTF and ERC grantees

- Received project grant/Science Chair from WWTF before ERC grant

- Partner in a WWTF project, WWTF grant received before ERC grant

- Pl in a WWTF project, ERC grant received before WWTF grant 


\begin{tabular}{|c|c|c|c|c|c|c|}
\hline Name & Award & Institution & PI or Partner & Yr WWTF grant & Yr FWF grant & WWTF area \\
\hline Jan-Michel Peters & FWF Wittgenstein & IMP & $\mathrm{PI}$ & 2009 & 2011 & LS \\
\hline Jürgen Knoblich & FWF Wittgenstein & IMBA & $\mathrm{PI}$ & 2005 & 2009 & LS \\
\hline Barry J. Dickson & FWF Wittgenstein & IMBA & Partner & 2005 & 2005 & LS \\
\hline Clemens Heitzinger & FWF Start & AIT/UWien & $\mathrm{PI}$ & 2009 & 2013 & MA \\
\hline Stefan Woltran & FWF Start & VUT & $\mathrm{Pl}$ & 2008 & 2013 & ICT \\
\hline Peter Balazs & FWF Start & AAS & $\mathrm{Pl}$ & 2007 & 2011 & MA \\
\hline Agata Ciabattoni & FWF Start & VUT & $\mathrm{PI}$ & 2007 & 2011 & MA \\
\hline Thorsten Schumm & FWF Start & VUT & Partner & 2007 & 2009 & MA \\
\hline
\end{tabular}

Table 18: WWTF and major FWF awards (START and Wittgenstein)

- PI in a WWTF project, WWTF grant received before FWF grant

- Partner in a WWTF project, WWTF grant received before FWF grant

\section{WWTF juries}

\begin{tabular}{lclc}
\hline WWTF juries & & & \\
\hline No. of Calls & 27 & $\begin{array}{l}\text { Average no. of jury } \\
\text { members }\end{array}$ & 9.7 \\
\hline Total no. of jury & 262 & No. of nations involved & 22
\end{tabular}

members

Table 19: Overall jury statistics

For this statistics also the programmes "Science for creative industries" and

"Cognitive Sciences" have been included. Only those jury members are counted

that took part in the final meeting and thus in the definite decision-making. 10

additional persons were part of the jury but could not attend the final meeting.

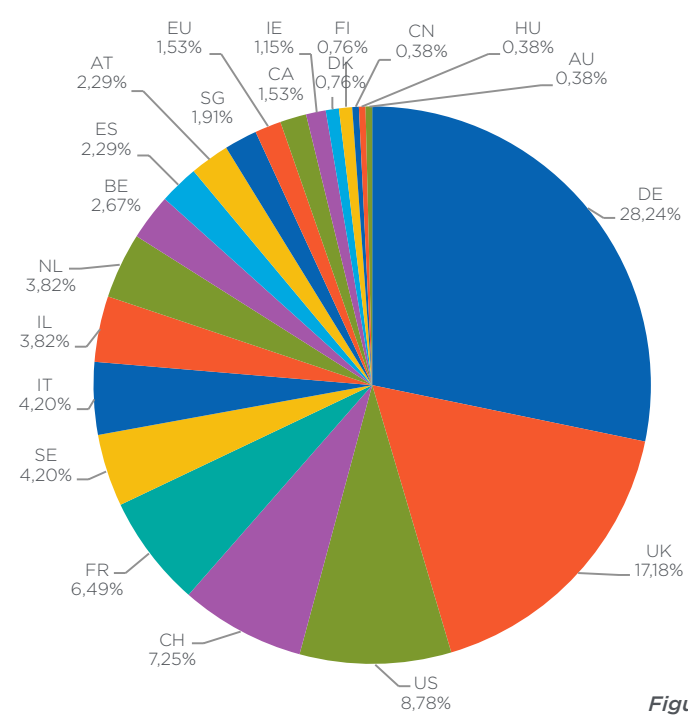

Figure 20: National distribution of WWTF jury members (nationality of jury members' institutional affiliation)
Figure 21: Regional distribution of WWTF jury members (nationality of jury members' institutional affiliation) 


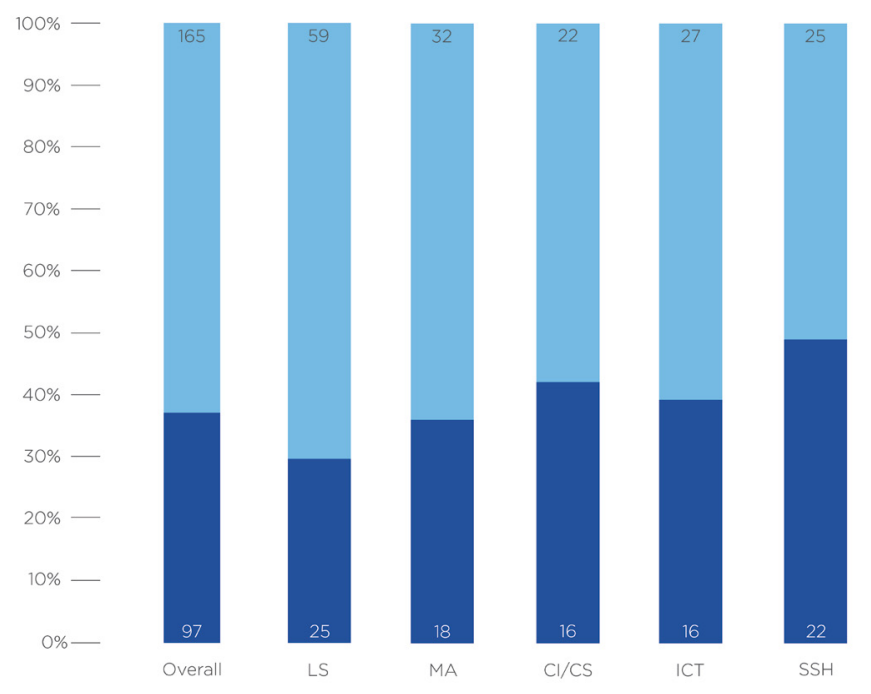

Figure 22: Gender distribution of jury members

- Female jury members

- Male jury members

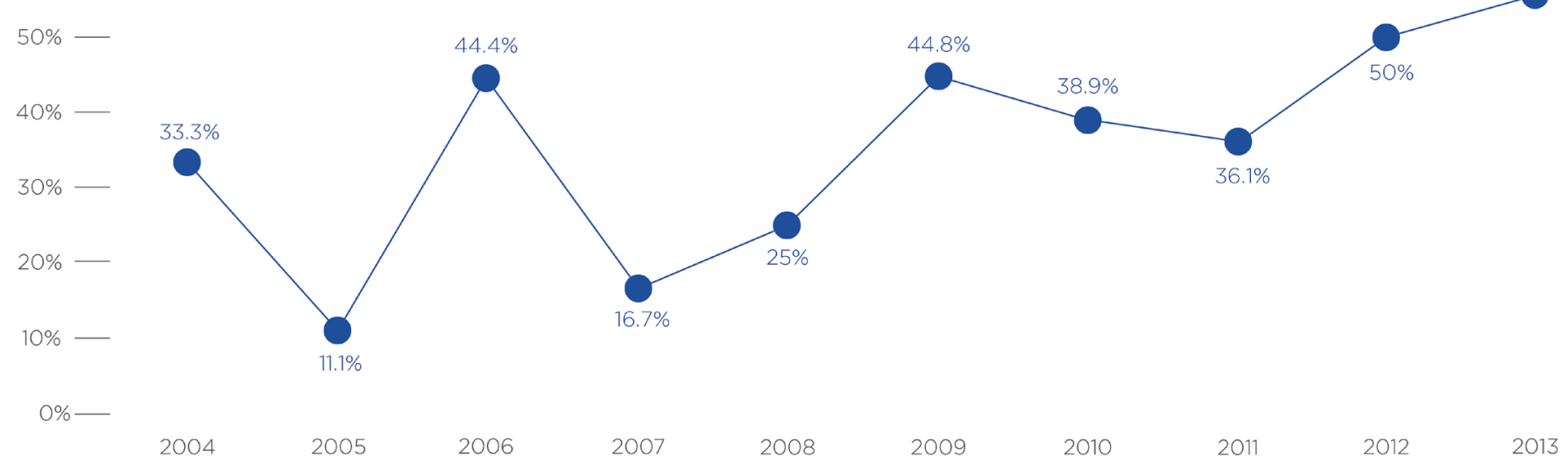

Figure 23: Share of female jury members in WWTF juries / year 


\section{Lists of WWTF jury members}

Chairmen and chairwomen are printed bold.

Non-voting members are marked with a *

Life Sciences Call 2003 is not included in the list. The jury was composed of members of WWTF Advisory Board and other Austrian experts from outside Vienna. The calls "Science for creative industries" and "Cognitive Sciences" are excluded. Institutions refer to employments at the time of the jury.

\section{4 / Science Chair - Bioinformatics}

\begin{tabular}{ll} 
Barton, Geoffrey & University of Dundee, UK \\
\hline Brazma, Alvis & EMBL Hinxton, EBI, UK \\
\hline de Daruvar, Antoine & $\begin{array}{l}\text { Université Victor Segalen } \\
\text { Bordeaux 2, FR }\end{array}$ \\
\hline Holm, Liisa & University of Helsinki, FI \\
\hline Linial, Michal & $\begin{array}{l}\text { Hebrew University Jerusalem, } \\
\text { IL }\end{array}$ \\
\hline Oliva, Thomas* & $\begin{array}{l}\text { Federation of Austrian Industry, } \\
\text { AT }\end{array}$ \\
\hline Ouzounis, Christos & EMBL Hinxton, EBI, UK \\
\hline Tramontano, Anna & $\begin{array}{l}\text { University of Rome „La } \\
\text { Sapienza“, IT }\end{array}$ \\
Valencia, Alfonso & $\begin{array}{l}\text { Centro National de } \\
\text { Biotecnologia, Madrid, ES }\end{array}$ \\
\hline Wick, Georg* & Austrian Science Fund, AT \\
\hline
\end{tabular}

\section{4/2005 / Mathematics and ...}

\begin{tabular}{ll} 
Björk, Tomas & $\begin{array}{l}\text { Stockholm School of } \\
\text { Economics, SE }\end{array}$ \\
$\begin{array}{l}\text { Bonhoeffer, } \\
\text { Sebastian }\end{array}$ & ETH Zurich, CH \\
\hline Flaschel, Peter & University of Bielefeld, DE
\end{tabular}

2004/2005 / Mathematics and ... (cont.)

\begin{tabular}{ll} 
Gilg, Albert B. & Siemens AG Munich, DE \\
\hline Grötschel, Martin & Zuse Institute Berlin, DE \\
\hline Neunzert, Helmut & Fraunhofer ITWM, DE \\
\hline Ockendon, Hilary & University of Oxford, UK \\
\hline Oliva, Thomas & Federation of Austrian Industry, \\
& AT \\
\hline Schmidt, Arnold & $\begin{array}{l}\text { Vienna University of } \\
\text { Technology, AT }\end{array}$ \\
Sparr, Gunnar & Lund University, SE \\
Sporn, Barbara & Wirtschaftsuniversität Wien, AT
\end{tabular}

\section{5 / Life Sciences}

\begin{tabular}{ll}
\hline Aguzzi, Adriano & University of Zurich, $\mathrm{CH}$ \\
\hline Bach, Fritz & Harvard Medical School, US \\
\hline Colman, Alan & $\begin{array}{l}\text { ES Cell International Pte Ltd } \\
\text { (ESI), SG }\end{array}$ \\
\hline Hartmann, Uwe & University of Saarbrücken, DE \\
\hline Hodits, Regina & Atlas Venture Munich, DE \\
\hline Inzé, Dirk & Ghent University, BE \\
\hline Linial, Michal & Hebrew University Jerusalem, \\
& IL \\
\hline Mann, Matthias & Max Planck Institut für \\
& Biochemie, DE \\
\hline Wigzell, Hans & Karolinska Institute, SE
\end{tabular}

\section{6 / Science Chairs Mathematics and ...}

Agur, Zvia

Institute for Medical BioMathematics, IL

Birney, Ewan
European Bioinformatics Institute, UK 


\begin{tabular}{|c|c|}
\hline Davis, Mark & Imperial College London, UK \\
\hline $\begin{array}{l}\text { Fleischmann, } \\
\text { Bernhard }\end{array}$ & University of Augsburg, DE \\
\hline Geman, Hélyette & $\begin{array}{l}\text { Birkbeck University of London, } \\
\text { UK }\end{array}$ \\
\hline Lenstra, Jan Karel & $\begin{array}{l}\text { Centrum voor Wiskunde en } \\
\text { Informatica, NL }\end{array}$ \\
\hline Maini, Philip K. & University of Oxford, UK \\
\hline Stevens, Angela & $\begin{array}{l}\text { Max Planck Institute for } \\
\text { Mathematics in the Sciences, } \\
\text { DE }\end{array}$ \\
\hline
\end{tabular}

\section{7 / Life Sciences}

\begin{tabular}{ll} 
Adler, Guido & University of Ulm, DE \\
\hline Aguzzi, Adriano & University of Zurich, CH \\
\hline Bach, Fritz & Harvard Medical School, US \\
\hline Colman, Alan & $\begin{array}{l}\text { Singapore Stem Cell } \\
\text { Consortium, SG }\end{array}$ \\
\hline Day, Simon & Roche Products Limited, UK \\
\hline Fraefel, Cornel & University of Zurich, CH \\
\hline George, Andrew & Imperial College London, UK \\
\hline Hartmann, Henrike & Volkswagen Foundation, DE \\
\hline Hodits, Regina & Atlas Venture Munich, DE \\
\hline Parmiani, Giorgio & $\begin{array}{l}\text { San Raffaele Foundation } \\
\text { Scientific Inst., IT }\end{array}$ \\
\hline Platt, Jeffrey L. & Mayo Clinic, US \\
\hline Todd-Pokropek, & University College London, UK \\
Andrew & $\begin{array}{l}\text { Cancer Research Center } \\
\text { Heidelberg, DE }\end{array}$ \\
\hline zur Hausen, Harald &
\end{tabular}

2007 / Mathematics and ...

\begin{tabular}{|c|c|}
\hline Bendsøe, Martin & $\begin{array}{l}\text { Technical University of } \\
\text { Denmark, DK }\end{array}$ \\
\hline Capasso, Vincenzo & $\begin{array}{l}\text { Universita degli Studi di Milano, } \\
\text { IT }\end{array}$ \\
\hline Geman, Hélyette & $\begin{array}{l}\text { Birkbeck University of London, } \\
\text { UK }\end{array}$ \\
\hline Gilg, Albert B. & Siemens AG Munich, DE \\
\hline Harel, David & $\begin{array}{l}\text { The Weizmann Institute of } \\
\text { Science, IL }\end{array}$ \\
\hline Jäger, Willi & University of Heidelberg, DE \\
\hline Labbé, Martine & Université libre de Bruxelles, BE \\
\hline Lewenstein, Maciej & ICFO Barcelona, ES \\
\hline Nieminen, Risto & $\begin{array}{l}\text { Aalto University School of } \\
\text { Science, FI }\end{array}$ \\
\hline Schmitz, Norbert & $\begin{array}{l}\text { Westfälische Wilhelms- } \\
\text { Universität Münster, DE }\end{array}$ \\
\hline Sparr, Gunnar & Lund University, SE \\
\hline
\end{tabular}

2008 / Information and Communication Technology

Broy, Manfred Technical University of Munich, DE

\begin{tabular}{ll}
\hline Buneman, Peter & University of Edinburgh, UK \\
\hline Caire, Giuseppe & $\begin{array}{l}\text { University of Southern } \\
\text { California, US }\end{array}$ \\
\hline Duda, Andrzej & $\begin{array}{l}\text { Grenoble Institute of } \\
\text { Technology, FR }\end{array}$ \\
\hline $\begin{array}{l}\text { Ghannouchi, Fadhel } \\
\text { M. }\end{array}$ & University of Calgary, CA \\
\hline Jarke, Matthias & RWTH Aachen University, DE \\
\hline Leuthold, Jürg & University of Karlsruhe, DE
\end{tabular}




\begin{tabular}{ll}
\hline $\begin{array}{l}2008 \text { / Information and Communication Technology } \\
\text { (cont.) }\end{array}$ \\
$\begin{array}{ll}\text { Magnenat-Thalman, } \\
\text { Nadja }\end{array}$ & University of Geneva, CH \\
\hline $\begin{array}{l}\text { Ottersten, Björn } \\
\text { Royal Institute of Technology, } \\
\text { SE }\end{array}$ \\
$\begin{array}{ll}\text { Palamidessi, } \\
\text { Catuscia }\end{array}$ & École Polytechnique, FR \\
\hline Pigneur, Yves & University of Lausanne, CH \\
\hline Staab, Steffen & University of Koblenz, DE \\
\hline Sziranyi, Tamas & $\begin{array}{l}\text { Hungarian Academy of } \\
\text { Sciences, HU }\end{array}$ \\
\hline
\end{tabular}

\begin{tabular}{|c|c|}
\hline $\begin{array}{l}2008 \text { / Science Ch } \\
\text { Sciences }\end{array}$ & - Quantitative Methods in Life \\
\hline $\begin{array}{l}\text { Bonhoeffer, } \\
\text { Sebastian }\end{array}$ & ETH Zurich, CH \\
\hline Capasso, Vincenzo & University of Milano, IT \\
\hline Doebeli, Michael & $\begin{array}{l}\text { University of British Columbia, } \\
\text { CA }\end{array}$ \\
\hline Milinski, Manfred & $\begin{array}{l}\text { Max Planck Institute for } \\
\text { Evolutionary Biology, DE }\end{array}$ \\
\hline $\begin{array}{l}\text { Weisser, Wolfgang } \\
\text { W. }\end{array}$ & University of Jena, DE \\
\hline
\end{tabular}

\section{8 / Social Sciences and Humanities}

\begin{tabular}{ll} 
Born, Georgina & University of Cambridge, UK \\
\hline Diner, Dan & Simon-Dubnow-Institut, DE \\
\hline Groys, Boris & $\begin{array}{l}\text { Institut für Kunstwissenschaft } \\
\text { und Medientheorie, DE }\end{array}$ \\
\hline Hennion, Antoine & École des Mines de Paris, FR \\
\hline Kemp, Martin & Trinity College, UK
\end{tabular}

2008 / Social Sciences and Humanities (cont.)

\begin{tabular}{ll} 
Nowotny, Helga & European Research Council, EU \\
\hline Obrist, Hans Ulrich & Serpentine Gallery, London, UK \\
\hline Ronte, Dieter & Forum Frohner, AT \\
\hline Wagner, Monika & University of Hamburg, DE \\
$\begin{array}{l}\text { Wegenstein, } \\
\text { Bernadette }\end{array}$ & John Hopkins University, US \\
Weigel, Sigrid & $\begin{array}{l}\text { Zentrum für Literatur- und } \\
\text { Kulturforschung Berlin, DE }\end{array}$ \\
\hline
\end{tabular}

\section{9 / Life Sciences}

\begin{tabular}{ll}
\hline Aguzzi, Adriano & University of Zurich, CH \\
\hline Betzel, Christian & University of Hamburg, DE \\
\hline $\begin{array}{l}\text { Bogoyevitch, Marie } \\
\text { Ann }\end{array}$ & University of Melbourne, AU \\
\hline $\begin{array}{l}\text { Colman, Alan } \\
\text { Singapore Stem Cell } \\
\text { Consortium, SG }\end{array}$ \\
\hline $\begin{array}{l}\text { George, Andrew } \\
\text { Imperial College London, UK }\end{array}$ \\
\hline Huebner, Kay & Atlas Venture Munich, DE \\
\hline Kay, Rob & MRC Laboratory Of Molecual \\
\hline Bartin, Cathie R. & John Innes Centre, UK \\
\hline $\begin{array}{l}\text { Schäfer-Korting, } \\
\text { Monika }\end{array}$ & Freie Universität Berlin, DE \\
\hline $\begin{array}{l}\text { Verstraete, Willy } \\
\text { Ghent University, BE }\end{array}$
\end{tabular}

2009 / Mathematics and ...

Baake, Ellen University of Bielefeld, DE

Buffa, Annalisa Istituto di Matematica Applicata e Tecnologie Informatiche, IT 


\section{9 / Mathematics and ... (cont.)}

\begin{tabular}{ll} 
Harel, David & $\begin{array}{l}\text { The Weizmann Institute of } \\
\text { Science, IL }\end{array}$ \\
\hline Kempe, Julia & Tel Aviv University, IL \\
\hline Klar, Axel & $\begin{array}{l}\text { Technische Universität } \\
\text { Kaiserslautern, DE }\end{array}$ \\
\hline $\begin{array}{l}\text { Klüppelberg, } \\
\text { Claudia }\end{array}$ & $\begin{array}{l}\text { Technical University of Munich, } \\
\text { DE }\end{array}$ \\
\hline Lenstra, Jan Karel & $\begin{array}{l}\text { Eindhoven University of } \\
\text { Technology, NL }\end{array}$ \\
\hline Lubkin, Sharon R. & $\begin{array}{l}\text { North Carolina State University, } \\
\text { US }\end{array}$ \\
\hline Maini, Philip K. & University of Oxford, UK \\
\hline Rumpf, Martin & University of Bonn, DE \\
\hline
\end{tabular}

\section{9 / Social Sciences and Humanities}

\begin{tabular}{ll} 
Born, Georgina & University of Cambridge, UK \\
\hline deMarinis, Paul & Stanford University, US \\
\hline Diner, Dan & Simon-Dubnow-Institut, DE \\
\hline Hennion, Antoine & École des Mines de Paris, FR \\
\hline Kemp, Martin & Trinity College, UK \\
\hline Kemp, Sandra & $\begin{array}{l}\text { University of the Arts London, } \\
\text { UK }\end{array}$ \\
\hline Nowotny, Helga & European Research Council, EU \\
\hline Ronte, Dieter & Forum Frohner, AT \\
Wagner, Monika & University of Hamburg, DE \\
Wegenstein, & John Hopkins University, US \\
Bernadette &
\end{tabular}

2010 / Information and Communication Technology

\begin{tabular}{ll}
\hline Acin, Antonio & ICFO Barcelona, ES \\
\hline Buhl, Hans Ulrich & University of Augsburg, DE \\
\hline Cucchiara, Rita & $\begin{array}{l}\text { Università degli Studi di } \\
\text { Modena, IT }\end{array}$ \\
\hline Feldmann, Anja & $\begin{array}{l}\text { Technische Universität Berlin, } \\
\text { DE }\end{array}$ \\
\hline Ghannouchi, Fadhel & University of Calgary, CA \\
M. & University of Paderborn, DE \\
\hline Hellebrand, Sybille & $\begin{array}{l}\text { Georgia Institute of } \\
\text { Ingram, Mary Ann }\end{array}$ \\
\hline Inverardi, Paola & Università dell'Aquila, IT \\
\hline Lapidoth, Amos & ETH Zurich, CH \\
\hline O'Sullivan, Carol & Trinity College Dublin, IR \\
\hline Rosenblum, David S. & University College London, UK \\
\hline Rumpe, Bernhard & Aachen University, DE \\
\hline Utschick, Wolfgang & $\begin{array}{l}\text { Technical University of Munich, } \\
\text { DE }\end{array}$ \\
\hline Wahlster, Wolfgang & $\begin{array}{l}\text { German Research Centre for } \\
\text { Al, DE }\end{array}$ \\
\hline Wolf, Alexander L. & Imperial College London, UK \\
\hline
\end{tabular}

\begin{tabular}{ll}
\hline 2010 / Vienna Research Groups - Life Sciences \\
\hline Colman, Alan & $\begin{array}{l}\text { A*STAR Institute of Medical } \\
\text { Biology, SG }\end{array}$ \\
\hline Fiebiger, Edda & Harvard Medical School, US \\
\hline Hartmann, Henrike & Volkswagen Foundation, DE \\
\hline Huebner, Kay & Ohio State University, US \\
\hline Inzè, Dirk & Ghent University, BE \\
\hline Linial, Michal & Hebrew University Jerusalem, \\
\hline Mason, Chris & IL \\
\hline
\end{tabular}


2010 / Science Chairs - Mathematics and ...

\begin{tabular}{ll} 
Deelstra, Griselda & Université libre de Bruxelles, BE \\
$\begin{array}{ll}\text { Klüppelberg, } \\
\text { Claudia }\end{array}$ & $\begin{array}{l}\text { Technical University of Munich, } \\
\text { DE }\end{array}$ \\
\hline $\begin{array}{l}\text { Lenstra, Jan Karel } \\
\text { Echmindhoven University of } \\
\end{array}$ & $\begin{array}{l}\text { Technology, NL } \\
\text { Westfälische Wilhelms- } \\
\text { Universität Münster, DE }\end{array}$
\end{tabular}

\section{0 / Social Sciences and Humanities}

\begin{tabular}{ll} 
Born, Georgina & University of Cambridge. UK \\
\hline Guiraudon, Virginie & University of Lille, FR \\
\hline Hannerz, UIf & Stockholm University, SE \\
\hline Liebig, Thomas & OECD Paris, FR \\
\hline Lucassen, Leo & Leiden University, NL \\
\hline Nowotny, Helga & European Research Council, EU \\
\hline Randeria, Shalini & University of Zurich, CH \\
\hline Schroeder, & University of Potsdam, DE \\
Christoph & \\
\hline Schröer, Wolgang & University of Hildesheim, DE \\
\hline Scott, Kirk & Lund University, SE \\
Vertovec, Steven & $\begin{array}{l}\text { Max Planck Institute for the } \\
\text { Study of Religious and Ethnic } \\
\end{array}$ \\
\hline
\end{tabular}

\section{1 / Vienna Research Groups - Information and} Communication Technology

Buhl, Hans Ulrich University of Augsburg, DE

Feldmann, Anja Technische Universität Berlin DE

\begin{tabular}{ll}
\hline $\begin{array}{l}\text { 2011 / Vienna Research Groups - Information and } \\
\text { Communication Technology (cont.) }\end{array}$ \\
\hline $\begin{array}{ll}\text { The Weizmann Institute of } \\
\text { Science, IL }\end{array}$ \\
\hline O'Sullivan, Carol & Trinity College Dublin, IR \\
\hline Ottersten, Björn & $\begin{array}{l}\text { Royal Institute of Technology, } \\
\text { SE }\end{array}$ \\
\hline Wolf, Alexander L. & Imperial College London, UK \\
\hline Rodden, Tom & University of Nottingham, UK \\
\hline & \\
\hline 2011 / Life Sciences & \\
\hline Chapman, Karen & University of Edinburgh, UK \\
\hline De Bari, Cosimo & University of Aberdeen, UK \\
\hline George, Andrew & Imperial College London, UK \\
\hline Glass, Liz & University of Edinburgh, UK \\
\hline Henske, Elizabeth & Harvard Medical School, US \\
\hline Hodits, Regina & $\begin{array}{l}\text { Wellington Partners, Munich, } \\
\text { DE }\end{array}$ \\
\hline Lee, Bruce Y. & University of Pittsburgh, US \\
\hline Lewis, Basil & $\begin{array}{l}\text { Technion Israel Institute of } \\
\text { Technology, IL }\end{array}$ \\
\hline Matthews, Paul & Imperial College London, UK \\
\hline Peeper, Daniel & $\begin{array}{l}\text { Vrije Universiteit Amsterdam, } \\
\text { NL }\end{array}$ \\
\hline Van Lenthe, Harry & ETH Zurich, CH \\
\hline
\end{tabular}

2011 / Social Sciences and Humanities

Guiraudon, Virginie University of Lille, FR

Kalter, Frank University of Mannheim, DE 
2011 / Social Sciences and Humanities (cont.)

\begin{tabular}{ll} 
Keith, Michael & University of Oxford, UK \\
\hline Lucassen, Leo & Leiden University, NL \\
\hline Nowotny, Helga & European Research Council, EU \\
\hline Randeria, Shalini & University of Zurich, CH \\
\hline $\begin{array}{l}\text { Schroeder, } \\
\text { Christoph }\end{array}$ & University of Potsdam, DE \\
Schröer, Wolgang & University of Hildesheim, DE \\
Scott, Kirk & Lund University, SE \\
\hline
\end{tabular}

\section{2 / Information and Communication Technology}

\begin{tabular}{ll} 
Acin, Antonio & ICFO Barcelona, ES \\
\hline Aïssa, Sonia & INRS, FR \\
\hline Buhl, Hans Ulrich & University of Augsburg, DE \\
\hline $\begin{array}{l}\text { Duel-Hallen, } \\
\text { Alexandra }\end{array}$ & US \\
\hline Gross, Markus & ETH Zurich, CH \\
\hline Inverardi, Paola & Università dell'Aquila, IT \\
\hline Issarny, Valérie & INRIA Paris, FR \\
\hline Keim, Daniel & University of Konstanz, DE \\
Kermarrec, Anne- & INRIA Rennes, FR \\
Marie & \\
Kwiatkowska, Marta & University of Oxford, UK
\end{tabular}

\section{2 / Life Sciences}

$\begin{array}{ll}\text { Beck, Thomas } & \text { Nestlé Research Lausanne, } \mathrm{CH} \\ \begin{array}{l}\text { Brigelius-Flohé, } \\ \text { Regina }\end{array} & \text { University of Potsdam, DE } \\ \begin{array}{ll}\text { Cocolin, Luca } & \text { Università degli Studi di Torino, } \\ & \text { IT }\end{array}\end{array}$

\begin{tabular}{|c|c|}
\hline \multicolumn{2}{|c|}{2012 / Life Sciences (cont.) } \\
\hline Daniel, Hannelore & $\begin{array}{l}\text { Technical University of Munich, } \\
\text { DE }\end{array}$ \\
\hline Janssens, Geert & Ghent University, BE \\
\hline Poulsen, Lars K. & University of Copenhagen, DK \\
\hline Prentice, Ann & $\begin{array}{l}\text { MRC Human Nutrition } \\
\text { Research, UK }\end{array}$ \\
\hline Saris, Wim & Maastricht University, NL \\
\hline Schön, Chris-Carolin & $\begin{array}{l}\text { Technical University of Munich, } \\
\text { DE }\end{array}$ \\
\hline Spranger, Joachim & Charité Berlin, DE \\
\hline Wüst, Matthias & University of Bonn, DE \\
\hline
\end{tabular}

\section{2 / Vienna Research Groups - Mathematics and ...}

Bonhoeffer, $\quad$ ETH Zurich, $\mathrm{CH}$

Sebastian

Del Bono, Emilia University of Essex, UK

Gilbert, Anna C. University of Michigan, US

Lewenstein, Maciej ICFO Barcelona, ES

Maini, Philip K. University of Oxford, UK

Van Keilegom, Ingrid Université catholique de Louvain, BE

Wohlmuth, Barbara Technical University of Munich, DE

\section{3 / Social Sciences and Humanities}

Bensaude-Vincent, Université Paris I Panthéon-

Bernadette Sorbonne, FR

Born, Georgina University of Oxford, UK

Gaver, Bill Goldsmiths, University of London, UK 
2013 / Social Sciences and Humanities (cont.)

\begin{tabular}{ll} 
Guiraudon, Virginie & Université Lille 2, FR \\
\hline Guy, Simon & University of Manchester, UK \\
\hline Nowotny, Helga & European Research Council, EU \\
\hline Rohracher, Harald & Linköping University, SE \\
\hline Staeheli, Lynn & Durham University, UK \\
\hline Thimm, Caja & University of Bonn, DE \\
Watson, Sophie & Open University, UK \\
Zimmer, Robert & Goldsmiths, University of \\
& London, UK
\end{tabular}

\section{3 / Life Sciences}

\begin{tabular}{ll} 
Al Haj, Alicia & Keele University, UK \\
\hline Krämer, Ute & Ruhr-Universität Bochum, DE \\
\hline Lasko, Paul & McGill University, CA \\
Mackintosh, Fred & University of Amsterdam, NL \\
\hline Martin, Cathie R. & John Innes Centre, UK \\
\hline Reddington, Martin & HFSP Organization, DE \\
\hline Rhodes, Daniela & Nanyang Technological \\
& University, SG \\
\hline Sansonett, Philippe & Institut Pasteur, FR \\
J. & \\
\hline $\begin{array}{l}\text { Sebastian Galles, } \\
\text { Nuria }\end{array}$ & Universitat Pompeu Fabra, ES \\
\hline $\begin{array}{l}\text { Tramontano, } \\
\text { Anna }\end{array}$ & \begin{tabular}{l} 
Sapienza, IT \\
\hline
\end{tabular}
\end{tabular}

\section{List of funded projects}

A list of all WWTF funded projects and a searchable project database can be found at www.wwtf.at 



$$
\mathrm{W}|\mathrm{W}| \mathrm{T} \mid \mathrm{F}
$$ \\ $\mathrm{W}|\mathrm{W}| \mathrm{T} \mid \mathbf{F}$}

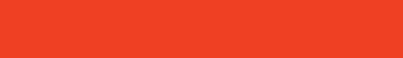

